This PDF is a selection from an out-of-print volume from the National Bureau of Economic Research

Volume Title: International Volatility and Economic Growth: The First Ten Years of The International Seminar on Macroeconomics

Volume Author/Editor: Georges de MÃ@nil and Robert J. Gordon, editors

Volume Publisher: Elsevier Science Publishers B.V., 1991

Volume ISBN: 0-444-89284-2

Volume URL: http://www.nber.org/books/de_m91-2

Conference Date: various

Publication Date: January 1991

Chapter Title: Productivity, Wages, and Prices Inside and Outside of Manufacturing in the U.S., Japan, and Europe

Chapter Author: Robert J. Gordon

Chapter URL: http://www.nber.org/chapters/c11679

Chapter pages in book: (p. 153 - 207) 


\title{
PRODUCTIVITY, WAGES, AND PRICES INSIDE AND OUTSIDE OF MANUFACTURING IN THE U.S., JAPAN, AND EUROPE*
}

\author{
Robert J. GORDON \\ Northwestern University, Evanston, IL 60201, USA \\ National Bureau of Economic Research, Washington, DC, USA
}

\section{Introduction}

\subsection{The issues}

On the eastern side of the Atlantic only one great economic puzzle of the 1980s is acknowledged: persistently high unemployment in Europe. Faced with an unwillingness of policymakers to reduce unemployment by expanding aggregate demand, many economists and commentators have retreated into cataloguing a litany of European supply-side maladies. To construct this list of ills, Europeans often cast envious glances toward America and Japan to reveal those aspects of European economic institutions that are different, and hence 'worse'.

Based on a new data set and a methodology that differs from most past research on comparative macroeconomic behavior, this paper argues that, whatever other differences between Europe and the U.S. may exist, any differences in the cyclical dynamics of productivity, wage, and price behavior have been greatly exaggerated. There is little evidence to support previous claims that, in comparison with the U.S., Europe exhibits (a) classical shortrun diminishing returns in the relationship between output and labor input, (b) greater 'rigidity' of real wage behavior, or (c) greater 'flexibility' of nominal wage and price behavior. The absence of a case supporting a unique set of cyclical aggregate supply responses in Europe undermines the case against policies that expand the growth rate of nominal aggregate demand in order to raise output and reduce unemployment in Europe. The main emphasis in this paper is on comparisons between Europe and the U.S.;

\footnotetext{
*This research has been supported by the National Science Foundation and the German Marshall Fund. I am grateful to Jacques Artus for contributing segments of the data, to Daniel Shiman for creating the data bank, and for helpful comments to William Branson, Heinz Konig, and participants in workshops at the Institut fur Weltwirtschaft, Kiel and the Centre for Labour Economics, London School of Economics. I owe special thanks to Clarissa Compaq and Ronald Rats for helping me with the estimation, and to Wanda Wordperfect for impeccable secretarial assistance.
} 
however, evidence for Japan is also presented that confirms important differences between Japan and both Europe and the U.S.

\subsection{The central role of the real wage}

Evaluations of the European unemployment problem often center around a distinction between Keynesian and classical unemployment, in which the real wage plays a central role. Evidence for classical unemployment is provided by a demonstration that growth in European real wages has been excessive, and that employment responds negatively to an increase in the real wage. A widely discussed summary measure of the excess component of the real wage, popularized by Bruno and Sachs $(1981,1985)$ and Sachs (1979, 1983), is the 'wage gap', an index of the ratio of the real wage to labor's average product, which amounts simply to an index of labor's share in national income. In their analyses of European unemployment and stagflation, Bruno and Sachs have exhibited wage gap indexes that increase much more in Europe than in the U.S., and they, together with numerous other authors [especially Layard and Nickell (1984), Bean, Layard and Nickell (1985), and Newell and Symons (1985)] have shown that employment and labor hours exhibit a strong negative elasticity to changes in the real wage.

But the case for an excessive real wage as the crux of the European unemployment has been carried too far. The European problem of declining employment and rising unemployment is centered in the manufacturing sector, yet the European wage gap index for manufacturing has fallen steadily since the late 1970 s and is now well below the value of the same index for U.S. manufacturing. Even more inconvenient is the enormous rise in the Japanese wage gap, which dwarfs anything experienced in Europe, without any slowdown in the growth of labor input.

So much has been said about the evil of higher real wages that the benefits of higher real wages, enjoyed throughout history, seem to have been forgotten. The negative response of labor hours to an increase in the real wage implies a positive response of output per hour to the same increase. Indeed, substitution away from labor in response to an inexorable rise in the real wage has been at the heart of the economic growth process for centuries. In a statistical decomposition, we show below that a substantial component of accelerations and decelerations of productivity growth in Europe, Japan, and even in the U.S. can be attributed to the behavior of the wage gap.

The response of employment to changes in the real wage constitutes only half of the circle linking the two. The Phillips curve can be interpreted as postulating a positive response in the growth of the real wage to the level of detrended employment. Thus a stimulus to aggregate demand provides not only the direct benefit of raising output and employment, but also the indirect benefit of raising the real wage and creating substitution away from 
labor that boosts productivity and, if sustained, the nation's standard of living. With this dual benefit obtainable from demand expansion, the case against demand stimulation must rest with convincing evidence that such policies would create an unacceptable acceleration of inflation.

\subsection{The research agenda in this paper}

This paper is a comprehensive study of the interrelationships among productivity, wages, and prices in the U.S., Japan, and Europe. New statistical evidence is provided on the four major issues introduced above, (1) the behavior of an index of the wage gap (labor's share), corrected for a major conceptual error in past measures of this concept, (2) the response of employment and productivity to changes in the real wage and the wage gap, (3) the 'Phillips-curve' response of real wages to economic slack, and (4) the division of a nominal demand change between inflation and real output growth. While each of these four issues has been studied by numerous authors, the research undertaken here is unique in its data base, distinction between manufacturing and non-manufacturing, and econometric specification.

Almost all previous studies in this area have used data that are inconsistent by sector, leading to regressions in which the wage rate in the manufacturing sector is related to employment or unemployment in the aggregate economy. Yet in 1984 manufacturing value added was only 24 percent of total output in the U.S. and 29 percent in Europe. In contrast, this study is based on a consistent data base in which time series for 14 countries over the 1961-84 interval have been developed for the aggregate economy, for the manufacturing sector, and for the non-manufacturing (residual) sector. The data series available for all three sectors in each of the 14 countries include such variables as real value added, the value added deflator, compensation per hour, employment, and hours per employee. ${ }^{1}$ As we shall see, this distinction between sectors is important, for the interpretion of the productivity growth slowdown, as well as constructed 'wage gap' measures, display quite different time series behavior inside and outside of manufacturing.

A further innovation in the data base corrects an error in previous measures of the wage gap or 'labor's share'. While employment and personhours data include not only employees but also the self-employed, the income of the self-employed is included in the official OECD national accounting system as part of capital's 'operating surplus' rather than as part

\footnotetext{
${ }^{1}$ The 14 countries are (in the order listed in table 1) U.S., Canada, Japan, Austria, Belgium, Denmark, France, Germany, Italy, Netherlands, Norway, Sweden, Switzerland, and U.K. Countries included in the L.S.E. Centre for Labour Economics data bank, but excluded here, are Australia, Finland, Ireland, New Zealand, and Spain.
} 
of the income of labor. When the income of the self-employed, which the OECD calls 'household entrepreneurial income' is added to the compensation of employees and treated as part of labor's income share, the secular increase in labor's share in Europe and Japan, to which Bruno and Sachs have previously called attention, disappears almost entirely. Rather than criticizing the concept of the wage gap upon which previous investigators have based their claim that European unemployment is 'classical', this paper shows that the properly measured wage gap shows little if any secular increase not just in the U.S., but also in Europe and Japan.

To take advantage of the new information contained in the data base, all regression equations describing the behavior of productivity, wage, and price changes are estimated separately for the three sectors (aggregate, manufacturing, and non-manufacturing). To limit the scope and length of the paper, which would otherwise be unmanageable, results for the 11 European countries are not reported separately. Instead, an aggregate for 'Europe' has been constructed. Thus all results are presented in groups of nine, three sectors for three 'countries' (U.S., Japan, and Europe). ${ }^{2}$

The econometric specification builds on my own past research for the U.S. and hence differs markedly from most other work on these issues. Since unemployment rates by sector are conceptually meaningless, the measure of cyclical variability that enters the productivity, wage, and price equations is detrended sectoral output rather than the level of unemployment. All equations are estimated in first differences rather than levels in order to avoid spurious correlations among variables (especially productivity and the real wage) that display common changes in trend. Special attention is given to the response of real wage changes to the productivity growth slowdown that has occurred everywhere, an issue that is ignored in the majority of studies that include only a single constant term in equations explaining wage changes, and yet is essential in testing the hypothesis that real wage growth in Europe was too 'rigid' to respond to the post-1973 productivity growth slowdown. Wage and price equations are based on an explicit model of disequilibrium labor market adjustment, in contrast to some work [especially Newell and Symons (1985)] based on a market-clearing interpretation.

\subsection{Themes that emerge}

The results cast doubt on some of the contrasts between the U.S. and Europe that have received heavy emphasis in previous research. While we confirm the real-wage elasticity of labor input stressed in papers by Layard and Nickell and Newell and Symons, we find that the response of labor input and labor productivity to changes in the real wage is roughly similar in

\footnotetext{
${ }^{2}$ Canada is also omitted, since we saw no point in constructing a 'North American' aggregate that would be totally dominated by the U.S.
} 
the three countries, rather than being especially high in Europe. There is absolutely no evidence to support Sachs' (1983) claim that productivity in Europe is 'classical', varying countercyclically, in contrast to procyclical movements in the U.S.

The apparent consensus that European real wages are excessive is simplistic; in 1984 the European wage gap was lower than the U.S. wage gap in manufacturing but higher in non-manufacturing, creating problems for classical interpretations of unemployment in Europe where the great bulk of the employment decline has occurred in manufacturing. The high wage gaps in the non-manufacturing sector in Europe and Japan are shown to result almost entirely from the omission of self-employment income as part of labor's share in national income.

The wage and price equations estimated in the paper address the common distinction between real wage rigidity in Europe and nominal wage rigidity in the U.S. [see especially Branson and Rotemberg (1980)]. We find that the bulge in the wage gaps of Europe and Japan in the 1970s is not due primarily to a failure of real wages to decelerate in response to the post-1973 productivity growth slowdown, but rather results in large part from episodes of autonomous 'wage push' in Europe in the late 1960s and in Japan during 1973-74. In this sense, real wages in Europe and Japan were too flexible, rather than too rigid.

The nominal wage rigidity part of the Branson and Rotemberg dichotomy receives only partial support. Some specifications indicate roughly similar cyclical responsiveness of nominal wage rates in Europe and the U.S. for the aggregate economy, leaving only the manufacturing sector to support Branson and Rotemberg on the grounds that there is almost complete nominal rigidity for U.S. manufacturing. Yet what matters is the aggregate economy, and here the differences among the U.S., Japan, and Europe are minimal. Responses of the nominal wage rate to the output ratio are of roughly the same order of magnitude in the three aggregate economies, The sectoral division between manufacturing and non-manufacturing displays the expected result that there is little cyclical responsiveness of wage rates in U.S. manufacturing, but the unexpected result that there is also less cyclical responsiveness in Japanese manufacturing than in Europe, and more cyclical responsiveness in both the U.S. and European non-manufacturing sectors than in Japan. These results suggest that the emphasis in my own past research $(1982,1983)$ on the greater nominal wage rigidity in the U.S. than in Japan may be limited in applicability to the manufacturing sector, and that differences in nominal wage flexibility in the aggregate economy (and in the nonmanufacturing sector) may be much less than is commonly supposed.

\section{A disequilibrium wage and price adjustment model}

This section develops an explicit model of disequilibrium wage and price 
adjustment in the labor market. ${ }^{3}$ The approach is based on the assumption that the nominal wage rate adjusts in response to any change in the size of the gap between labor demand and supply. The advantage of the formulation is that the influence of supply shocks, of the post-1973 productivity slowdown, and of tax changes on wage and price behavior can be motivated concretely in the model. This section concludes by using the model to develop definitions of the much-discussed concepts of real and nominal wage stickiness, the output gap, and the natural rate of unemployment.

\subsection{The static labor market model}

The exposition begins with a production function in which output $\left(Q_{t}\right)$ is written as a function of labor input $\left(N_{t}\right)$ and a multiplicative factor $\Theta_{t}$ that incorporates the effects of capital and materials inputs and of technological change

$$
Q_{t}=\Theta_{t} Q\left(N_{t}\right), \quad Q^{\prime}>0 .
$$

The real product wage, which is set equal to the marginal product of labor, is expressed as the ratio of the actual wage rate, $W_{t}$, to the expected product price, $P_{t}^{\mathrm{e}}$, adjusted for the influence of indirect taxes, $T_{t}^{\mathrm{l}}$. Payroll taxes do not enter into the expression for the real product wage, because the wage concept in our data $\left(W_{t}\right)$ is measured gross of all payroll taxes paid by employers and employees

$$
\frac{W_{t} T_{t}^{\mathrm{I}}}{P_{t}^{\mathrm{c}}}=\Theta_{t} Q^{\prime}\left(N_{t}\right)
$$

Here the expression $T^{1}$ represents an indirect tax factor, defined as

$$
T^{1}=\left[\frac{1}{1-\tau^{\mathrm{l}}}\right]
$$

where $\tau^{\mathrm{I}}$ is the indirect tax rate.

Eq. (2), inverted, expresses the demand for labor as a function of the real expected product wage, adjusted for the tax term, $T_{t}^{\mathrm{l}}$, and the productivity shift factor, $\Theta_{\imath}$

$$
N_{t}^{\mathrm{d}}=N^{\mathrm{d}}\left[\frac{W_{t} T_{t}^{\mathrm{l}}}{\Theta_{\mathrm{t}} P_{t}^{\mathrm{e}}}\right], \quad N^{\mathrm{d}}<0
$$

${ }^{3}$ This model was first developed in Gordon (1977b) and was recently applied to the U.S. economy in Gordon (1985). The version set out here uses a different definition of the wage rate (gross of all employment taxes) and also solves out the consumer price index term that appears in previous versions of the model. 
The supply of labor is a positively sloped function of the real wage stated in terms of the expected consumer price index, $C_{t}^{\mathrm{e}}$, with an adjustment for a personal tax factor, $T_{t}^{\mathbf{P}}=\left[1 /\left(1-\tau_{t}^{\mathbf{P}}\right)\right] \cdot\left[1 /\left(1-\tau_{t}^{\mathrm{S}}\right)\right]$, where $\tau_{t}^{\mathbf{P}}$ is the personal tax rate and $\tau_{t}^{\mathrm{S}}$ is the total payroll tax rate on both employers and employees, included in our measure of the wage rate $\left(W_{t}\right)$

$$
N_{t}^{\mathrm{s}}=N^{\mathrm{s}}\left[\frac{W_{t}}{R_{t} T_{t}^{\mathrm{P}} C_{t}^{\mathrm{e}}}\right], \quad N^{\mathrm{s}}>0
$$

In eq. (4) the factor $R_{t}$ is the 'aspiration' real wage that workers compare with the tax-adjusted real expected wage.

The excess demand for labor, $X_{t}$, can be expressed as the ratio of labor demand to labor supply

$$
X_{t}=N_{t}^{\mathbf{d}} / N_{t}^{\mathbf{s}}
$$

so that in equilibrium $X_{t}=1$ and $\log X_{t}=0$. This expression can be converted into a relationship between the proportional rates of growth of the demand for and supply of labor by substituting eqs. (3) and (4) into eq. (5), taking time derivatives of the $\log$ version of $(5)$, and rearranging

$$
x_{t}=-(a+b)\left(w-\theta-p^{\mathrm{e}}\right)_{t}+b\left(r-\theta+c^{\mathrm{e}}-p^{\mathrm{e}}+t^{\mathrm{P}}\right)_{t}-a t_{t}^{\mathrm{I}}
$$

Here lowercase letters indicate rates of change $(w=\mathrm{d} \log W / \mathrm{d} t)$, and $a$ and $b$ are, respectively, the real-wage elasticities of labor demand and supply.

\subsection{The Phillips curve wage equation}

The Phillips curve adjustment hypothesis is that the nominal wage rate moves in the direction needed to eliminate the excess demand for labor at a rate that depends on the size of the gap between demand and supply

$$
x_{t}=-g \log \left(X_{t}\right)
$$

where once again lowercase letters represent proportional rates of change. Thus in equilibrium $x_{t}=\log \left(X_{t}\right)=0$. When the right-hand sides of eqs. (6) and (7) are set equal to each other and solved for the rate of change of real unit labor cost, the result is the augmented Phillips curve wage change equation

$$
w_{t}-\theta_{t}-p_{t}^{\mathbf{e}}=\frac{1}{a+b}\left[b\left(r-\theta+c^{\mathrm{e}}-p^{\mathrm{e}}+t^{\mathrm{P}}\right)_{t}-a t_{t}^{\mathrm{I}}+g \log \left(X_{t}\right)\right]
$$


Our subsequent reduced form equation is simplified if at this stage we eliminate the expected change in the consumer price index $\left(c_{t}^{c}\right)$ from (8) by assuming that the only difference between the changes in the consumer and producer price indexes $(c-p)$ is due to the difference between the change in import $\left(p_{t}^{F}\right)$ and export $\left(p_{t}^{\mathbf{X}}\right)$ prices

$$
c_{t}=p_{t}+j\left(p_{t}^{\mathrm{F}}-p_{t}^{\mathrm{X}}\right),
$$

where we apply the same weight $(j)$ to import and export prices on the assumption of balanced trade. If the rate of change of import and export prices is the same, then the $c-p$ term drops out. We shall make the alternative simplifying assumption that the growth rate of export prices is the same as that of domestic producer prices, so that

$$
(c-p)_{t}=j\left(p_{t}^{\mathrm{F}}-p_{t}\right)
$$

When (10) is substituted into (8), we obtain the modified augmented Phillips curve wage change equation

$$
w_{t}-\theta_{t}-p_{t}^{\mathrm{e}}=\frac{1}{a+b}\left\{b\left[r-\theta+j\left(p^{\mathrm{F}}-p\right)+t^{\mathrm{P}}\right]_{t}-a t_{t}^{\mathrm{t}}+g \log \left(X_{t}\right)\right\},
$$

where the distinction between the actual and expected change in the real import price term has been dropped.

\subsection{Price equations: Markup and reduced-form}

Eq. (11) describes the time series behavior of the rate of change in the nominal wage rate and in the wage gap $\left(w_{t}-\theta_{t}-p_{t}\right)$. To determine the cyclical behavior of the inflation rate to changes in demand or supply, (11) must be supplemented by an explicit hypothesis regarding the determination of prices. We assume that the product price is set as a weighted average of domestic unit labor cost adjusted for the indirect tax factor $T_{t}^{\mathrm{l}}$ introduced in eq. (2), and the import price $P_{t}^{F}$, with a variable markup, $M$, that depends on excess demand $\left(V_{t}\right)$ in the commodity market

$$
P_{t}=T_{t}^{1} M\left(V_{t}\right)\left(W_{t} / \Theta_{t}\right)^{h}\left(P_{t}^{\mathrm{F}}\right)^{1-h} .
$$

Although imports are excluded from the domestic value-added price index $(P)$, nevertheless the prices of foreign goods can influence domestic valueadded prices through their effect on import substitutes. The weight $h$ incorporates this effect, and $h$ would be expected to differ from the import share $j$ that appears above in eq. (10). 
By taking the time derivative of the logarithmic version of (12), we obtain an expression that relates the current inflation rate to the current rates of change of unit labor cost, foreign prices, excess commodity demand, and the indirect tax factor

$$
p_{t}=h\left(w_{t}-\theta_{t}\right)+(1-h) p_{t}^{\mathrm{F}}+t_{t}^{\mathrm{I}}+m\left(v_{t}\right) .
$$

Now, substituting the wage change eq. (11) into the price change equation (13), it is possible to obtain a reduced-form expression for the inflation rate that does not directly involve the wage rate

$$
\begin{aligned}
p_{t}= & p_{t}^{\mathrm{e}}+m\left(v_{t}\right)+\frac{h g \log \left(X_{t}\right)}{a+b} \\
& +\left[(1-h)+\frac{h b j}{a+b}\right]\left(p^{\mathrm{F}}-p\right)_{t}+\frac{1}{a+b}\left\{h b\left(r-\theta+t^{\mathbf{P}}\right)_{t}+[b+a(1-h)] t_{t}^{\mathbf{l}}\right\} .
\end{aligned}
$$

To interpret eq. (14), it helps to combine all of the terms on the second line into a single 'cost-push' or 'supply-shift' term $z_{t}$, where

$$
z_{t}=[(a+b)(1-h)+h b j]\left(p^{\mathbf{F}}-p\right)_{t}+\left\{h b\left(r-\theta+t^{\mathbf{P}}\right)_{t}+[b+a(1-h)] t_{t}{ }^{\mathbf{S}}\right\} .
$$

This definition allows us to write a more compact version of the reducedform inflation equation as

$$
p_{t}=p_{t}^{e}+m\left(v_{t}\right)+\frac{1}{a+b}\left[h g \log \left(X_{t}\right)+z_{t}\right] .
$$

This expression (16) is an expectational Phillips curve relating the actual inflation rate to the expected inflation rate and the growth $(v)$ and level $(\log X)$ of excess demand. When the economy is operating at a fixed level of excess demand, with $v_{t}=0$, inflation accelerates $\left(p_{t}>p_{t}^{e}\right)$ when the level of $\log \left(X_{t}\right)$ is positive and decelerates when $\log \left(X_{t}\right)$ is negative.

\subsection{Alternative interpretations of the natural rate hypothesis and the wage gap}

The presence of the cost-push term $\left(z_{t}\right)$ in (16) requires that we identify two concepts of the natural rate of unemployment. The 'conventional' or 'noshock' natural rate of unemployment $\left(U_{t}^{*}\right)$ is that which is consistent with zero excess demand in the labor market when the supply shock terms net out to zero $\left(z_{t}=0\right)$. With $z_{t}$ and $v_{t}$ set at zero in (16), then a steady rate of inflation, with $p_{t}=p_{t}^{e}$, is achieved whenever $\log \left(X_{t}\right)=0$. This situation also 
defines the natural unemployment rate $\left(U_{t}^{*}\right)$ as that which is consistent with zero excess demand in the labor market

$$
U_{t}^{*}=U_{t}+\log \left(X_{t}\right)
$$

where $U_{t}$ is the actual unemployment rate.

However, when the supply shock terms in (15) do not net out to zero $\left(z_{t} \neq 0\right)$, then the alternative 'shock' natural rate concept $\left(U_{t}^{\text {S }}\right)$ indicates the unemployment rate consistent with steady inflation

$$
U_{t}^{\mathrm{s}}=U_{t}^{*}+\frac{z_{t}}{g h}
$$

The cost-push or supply-shock factors appearing in (15) that may set the $z_{t}$ term at a non-zero value can be a cause of inflation, unemployment, or both. If the monetary authority accommodates the shocks by attempting to set $X_{t}=0$, then inflation will accelerate when $z_{t}>0$. If the authority extinguishes the shocks by attempting to maintain $p_{t}=p_{t}^{\mathrm{c}}$, then unemployment will rise above $U_{i}^{*}$ by the amount shown in eq. (18). Thus the three components of $z_{t}$ in (15) can be interpreted as causes of inflation, unemployment, or both, depending on the degree of monetary accommodation provided by the monetary authority

(1) There can be an increase in the real price of foreign goods expressed in domestic currency $\left(p^{\mathrm{F}}-p\right)$.

(2) There can be an excess in the growth rate $\left(r_{t}\right)$ of the 'aspiration' real wage relevant for labor supply over the growth rate of productivity $\left(\theta_{t}\right)$ that is relevant for price setting.

(3) There can be an increase in either of the two tax factors, personal or indirect.

\subsection{Interpretations of real and nominal wage rigidity}

Eqs. (15) and (18) help us gain insight into the interrelationship between real and nominal wage rigidity. The usual interpretation of real wage rigidity is an excess of workers' aspirations for real wage increases relative to the rate of productivity growth, i.e., that the term $\left(r_{t}-\theta_{t}\right)$ is positive in (15), presumably because of a failure of the rate of real wage increase to adjust downwards in response to a slowdown in productivity growth, such as that which occurred after 1973. Clearly, real wage flexibility in the sense that $r_{t}$ always stays equal to $\theta_{t}$ is necessary but not sufficient for an avoidance of classical unemployment, since the other terms on the right-hand side of (15) that comprise $z_{t}$ could have a positive sum. Conversely, real wage rigidity in 
the sense of an inflexible $r_{t}$ is not necessary for classical unemployment to occur, because real wage flexibility can be as serious a problem if there is an autonomous jump in $r_{t}$ while $\theta_{t}$ remains constant. Below we present evidence supporting the interpretation that an 'autonomous wage push' occurred in Europe in the late 1960s and in Japan in 1973-74.

Second, if all of the terms in (15) sum to zero, so that the supply shock term $z_{t}$ is zero, nominal wage rigidity in the sense of a small adjustment parameter $g$ in (18) is irrelevant to inflation and unemployment, as long as the economy begins in equilibrium with $\log \left(X_{t}\right)=0$ and matters only by raising the amount of employment or output that must be sacrificed to reduce the inflation rate from some initial value (thus there should be a direct correlation across countries between high values of $g$ and low sacrifice ratios).

Third, the effects of excess wage growth in the sense that $r_{t}>\theta_{t}$ cannot be separated from those of nominal wage rigidity, since in (18) the value of $U_{t}^{\mathrm{S}}$ required to maintain a constant value of the inflation rate depends both on the amount by which $r_{t}$ exceeds $\theta_{t}$ and on the nominal adjustment parameter $g$. If $g$ is quite small, then excess real wage growth can cause a large amount of unemployment when the monetary authority acts to prevent inflation from accelerating. More generally, the amount of unemployment that results from any positive component of the supply-shift $z_{t}$ term depends inversely on the size of the nominal wage adjustment parameter $g$.

\section{The data base and issues in econometric specification}

\subsection{The data base for manufacturing and non-manufacturing}

Most comparative econometric studies of wage and employment equations have indiscriminately mixed data on the hourly wage rate for the manufacturing sector with economy-wide data on unemployment and/or output. ${ }^{4}$ The work of Artus (1984) is almost unique in developing a consistent data base for manufacturing, and this paper builds on his research by developing an analogous data base for the aggregate economy, as well as the manufacturing and non-manufacturing (residual) sectors.

The aim of the data compilation is to develop consistent series on value added, the value added deflator, compensation, employment, and hours per employee. These series allow the calculation of all the variables that matter for a study of productivity, wage, and price behavior. Average labor produc-

\footnotetext{
${ }^{4}$ The LSE data base, as described by Grubb (1986), contains hourly earnings only for manufacturing, and not always on a consistent base. Data for Australia and Norway are for males only, data for the U.S. include production workers only, data for Austria, Belgium, Denmark, and Sweden include mining, data for Belgium include transport, and data for Spain include all industries.
} 
tivity is real value added per labor hour, the wage rate is compensation per labor hour, and the wage gap is the nominal wage rate, divided by the value added deflator, divided by average labor productivity. Because the real product wage relevant for the hiring decisions of business firms is expressed at factor cost, i.e., net of indirect taxes, special care has been taken to achieve a consistent set of net-of-tax product price deflators at factor cost.

A unique feature of this study is the symmetric attention to the manufacturing and non-manufacturing sectors. Data for the latter are created as a residual, from data on the absolute values of output, compensation, and labor input for the aggregate economy and for manufacturing. The manufacturing data come from the IMF quarterly data base derived from original national accounts sources, and the aggregate data are developed here from published OECD series, together with a crucial unpublished series on aggregate hours per employee. ${ }^{5}$

Another unique feature of the data base is the explicit treatment of selfemployment income. Previous studies have included in indexes of labor's income share and the 'wage gap' only the compensation of employees. But the income of the self-employed, consists mainly of labor income, should also be included rather than being hidden, as at present, in the OECD's umbrella capital income measure called 'the operating surplus'. This is particularly important in this study, which measures the wage rate as compensation per hour. Since measures of employment and total hours include the selfemployed, so should the measure of compensation. Thus our measure of total compensation adds the OECD measure of 'household entrepreneurial income' to employee compensation. We assume that most of this entrepreneurial income is earned in the agricultural, trade, and service sector, and so include it in the aggregate and in non-manuufacturing, but make no adjustment in the manufacturing sector. Below we display the effects of the entrepreneurial income adjustment on indexes of the 'wage gap'.

Because regression results are presented below for all three sectors, it is not possible to follow the usual format in such studies by providing separate regression estimates for each of the 14 countries covered in the data base. Instead, a 'Europe' aggregate for the 11 European countries has been compiled, using 1972 GNP weights expressed in dollars, and this allows the

\footnotetext{
${ }^{5}$ This unpublished series was provided by John Martin of the OECD. All other series for the aggregate sector were obtained from an OECD PC data diskette. The manufacturing data were transcribed manually from printouts provided by the IMF in May 1985 and include manufacturing value-added deflators, output, compensation, employment, and hours for the fourteen countries identified in footnote 2 . The compilation of the manufacturing data is described in the data appendix of Artus (1984). A critical step in the development of the data base was the location of data on the absolute value of each variable (particularly nominal output, nominal compensation, and labor hours) for each aggregate economy in 1972, in order to allow subtraction of manufacturing values from aggregate values to obtain the needed residual values.
} 
subsequent research to be carried out for three countries, the U.S., Japan, and 'Europe'.

Potential defects in these procedures are obvious and may be enumerated briefly. The use of compensation per hour to represent the wage rate has the advantage that separate wage rate series can be developed for the aggregate, manufacturing, and non-manufacturing sectors, but has the disadvantage that any compensation per hour series displays cyclical fluctuations created by changes in the fraction of hours paying overtime rates, and by changes in the interindustry mix between high and low wage activities, in addition to changes in the 'pure' wage rate itself. While my past work on U.S. wage behavior has been based on an hourly earnings index adjusted for shifts in overtime and the interindustry employment mix, such indexes are not available for other countries, and thus the need for consistency requires use of an unadjusted compensation per hour series for each country and each sector. The addition of self-employment income to employee compensation also raises issues that require further research, including the true breakdown between manufacturing and non-manufacturing, and the more difficult issue of separating the labor and capital components of entrepreneurial income.

Another limitation of our approach is the requirement that detrended output rather than the official or standardized unemployment rate be used as the basic measure of cyclical variability, simply because unemployment rate series are available only for the aggregate economy and are meaningless for sub-sectors. While the regressions presented below for the aggregate sector of the U.S., Japanese, and European economies could be reestimated with the unemployment rate replacing the detrended output series, this task would expand the scope of the paper and is deferred for future research.

\subsection{Converting the theoretical equations into an econometric specification}

The aim of the econometric research is to estimate equations for wage change (11), price change within a markup framework (13), and price change within a reduced-form framework (14). Decisions required to convert theoretical ideas into an explicit econometric specification are discussed here.

(l) Basic format. All equations take the form of (11), (13), and (14), by expressing all variables (other than the cyclical Phillips curve variable) as first differences of logs.

(2) Expected price change. The $p_{t}^{\mathrm{e}}$ term in eqs. (11) and (14) is proxied by two lags on the annual change in the value-added deflator. Two lags appear to be sufficient to explain the wage changes without including a third or further lags, while the 'zero' lag (current price change) is excluded to avoid simultaneity and identify the wage and price equations (i.e., the current 
change in unit labor cost is entered into the price markup equations, but the current change in price is not entered into the wage equations). This treatment reflects the (structural) assumption that wages can influence prices within the current year more than prices can influence wages, and the high degree of simultaneity between annual changes in wages and prices is attributed to the price-setting process. ${ }^{6}$ Note that the wage equation (11) calls for the expected price change term to enter with a unitary coefficient; the wage equations are estimated below with the sum of coefficients on the two lagged price change terms both estimated freely and also constrained to equal unity.

(3) Demand pressure variables. It has been customary in previous studies to designate the unemployment rate or its inverse as the sole demand pressure variable. However, in theory it is not the level of the unemployment rate that matters, but rather the excess demand for labor, which should be measured as the deviation of the actual from the natural unemployment rate. If the natural unemployment rate has risen, as seems to have occurred in most countries, the use of the unemployment rate to measure excess demand introduces measurement error. The procedure used here is to take advantage of the regular 'Okun's Law' relationship observed in many countries [Gordon (1984), Hamada and Kurosaka (1983)] in the form of a high negative correlation between the $\log$ ratio of actual to 'natural' output $\left(\log Q-\log Q^{*}\right)$ and the deviation of the actual from the natural unemployment rate. The required natural output series consists of exponential trends running between the benchmark years of 1961, 1972, and 1979, with the 1972-79 trend extended to 1984 on the assumption that most countries were operating below natural output after 1979 and hence that no benchmark year is available for the 1980 s. $^{7}$

The standardized unemployment rates for each country are shown in table 1 for the benchmark years 1961,1972 , and 1979 , and also for 1984 . While the U.S. in 1979 seems to have been operating close to natural output (Gordon, 1985), the choice of 1979 as a benchmark year is subject to debate for some of the other countries. The unemployment rate for Europe (the fourth line in table 1) rose from 2.7 percent in 1972 to 4.9 percent in 1979 , suggesting the possibility that setting natural output equal to actual output in 1979 for Europe may lead to an understatement of natural output and overstatement of the $\log$ output ratio for the entire post-1972 period.

\footnotetext{
${ }^{6}$ For a discussion of alternative methods of imposing structure on wage and price equations within this context, see Blanchard (1986). In some of his quarterly wage equations Blanchard imposes the structural assumption that the coeflicient on the current price change in the wage equation cannot be higher than a specified amount, e.g., 0.3 .

${ }^{7}$ Exceptions to this procedure are that 1984 is used as a benchmark year for Japan to take account of highly different growth rates of output during 1979-84 in manufacturing versus nonmanufacturing. Also, since 1961 was a recession year in North America, the first benchmark is 1964 in Canada and the U.S., and also in France. The 1961-64 growth rate of natural output for these countries is assumed to be equal to the observed 1964-72 growth rate.
} 
Table 1

Standardized unemployment rates, selected years.

\begin{tabular}{llllr}
\hline & 1961 & 1972 & 1979 & 1984 \\
\hline U.S. & 6.4 & 5.5 & 5.8 & 7.4 \\
Canada & 6.5 & 6.2 & 7.4 & 11.2 \\
Japan & 1.2 & 1.4 & 2.1 & 2.7 \\
Eleven European Countries & 1.7 & 2.7 & 4.9 & 9.6 \\
Austria & 1.9 & 1.2 & 2.1 & 4.1 \\
Belgium & 2.1 & 2.7 & 8.2 & 14.0 \\
Denmark & 2.0 & 0.9 & 6.1 & 10.1 \\
France & 1.4 & 2.7 & 6.0 & 9.7 \\
Germany & 0.3 & 0.8 & 3.2 & 8.6 \\
Italy & 5.1 & 6.3 & 7.5 & 10.2 \\
Netherlands & 0.5 & 2.2 & 5.4 & 14.0 \\
Norway & 1.8 & 1.7 & 2.0 & 3.0 \\
Sweden & 1.4 & 2.7 & 2.1 & 3.1 \\
Switzerland & 0.0 & 0.0 & 0.4 & 1.1 \\
U.K. & 2.2 & 4.3 & 5.6 & 13.2 \\
\hline
\end{tabular}

Source: Switzerland and Denmark, 1972 and 1979 from $O E C D$ Labor Force Statistics, 1984: OECD Economic Outlook, December 1985, p. 28.

Other countries for 1972, 1979, and 1984: OECD Economic Outlook, June 1985, table R12.

All countries for 1961: Yearbook of Labor Statistics, 1971, table 10, linked to OECD Series in 1964.

(4) Tax rates. There are insufficient degrees of freedom to include both tax change terms $\left(t^{1}\right.$ and $\left.t^{\mathrm{P}}\right)$ in annual equations for the short 1964-84 interval. Instead, the rate of change of the total indirect, payroll, and personal tax rates is entered as a single variable. The change in the total tax rate $\left(t^{\mathrm{T}}\right)$ is calculated at an annual rate over two years, rather than one year, to allow for lags without using up an extra degree of freedom.

(5) Productivity growth. The wage change equation (11) contains a term $(r-\theta)$ to allow for the possibility that the 'aspiration' real wage rate rises more rapidly than the rate of productivity growth $(\theta)$ relevant for price setting; this could reflect either real wage stickiness in response to a slowdown in productivity growth, or an autonomous episode of 'wage push' that is not captured by the other terms in the wage equation. The productivity growth concept assumed to be relevant for price setting is trend productivity growth $\left(\theta^{*}\right)$ rather than actual productivity growth $(\theta){ }^{8}$ Separate values of $\theta^{*}$ are

${ }^{8}$ The price change equations I have estimated for the U.S. over the years, as in Gordon (1965), include a productivity deviation $\left(\theta-\theta^{*}\right)$ term to measure the proportion of price setting behavior based on actual as opposed to trend productivity growth. The estimated proportion is usually in the range of 0.15 to 0.20 . This productivity deviation term is not included in the price equations estimated in this paper, thus imposing the restriction that price changes depend only on trend productivity growth with no role for actual productivity growth. 
estimated before and after 1972, as discussed in section 4, and are subtracted from the rate of wage change to form the dependent variable of the wage equation $\left(w_{t}-\theta_{t}^{*}\right.$, i.e., the change in trend unit labor cost).

The real-wage rigidity or wage push effect $(r-\theta)$, which we can call the 'excess change' in the real wage, is measured by a set of dummy variables. The first is simply a constant term for the full sample period. Since the specification in (11) contains no constant term, a significant positive value for the constant term would indicate that, on average over the sample period, the change in the real wage rate is larger than the trend growth rate of productivity, after taking account of the effect of the other variables in the equation (the $\log$ output ratio, the change in the two tax rates, and the relative import price change). Additional dummy variables are also entered for the 1973-84 and 1980-84 periods to test for the excess change in the real wage during different intervals of the sample period. The sum of the constant and the 1973-84 dummy indicates for the 1973-79 period the excess change in the real wage (measured as an annual rate of change), while the sum of the constant, the 1973-84 dummy, and the 1980-84 dummy indicates the excess change for the 1980-84 interval. This interpretation of the excess change in the real wage requires that the coefficients on the lagged product price change terms $\left(p_{t-1}\right.$ and $\left.p_{t-2}\right)$ are constrained to sum to unity. The wage equations are estimated both with and without the set of constants and dummy variables.

In previous research on European wage setting behavior Nordhaus (1972) identified a 'wage explosition' in the late 1960s, and this episode of autonomous wage push was confirmed later by Perry (1975) and Gordon (1977a). To isolate this episode, an additional dummy variable is included in the European wage equations, defined as 1.0 for the years 1968-70 and zero otherwise. While there have been no wage explosions in the U.S., allowance for the Nixon wage and price controls period in 1971-72 and subsequent rebound in 1974-75 needs to be made, and this is handled by a single dummy variable defined as 1.0 in $1971-72,-1.0$ in 1974-75, and zero otherwise. The fit of the Japanese wage equations is markedly improved when the period 1973-74 is treated as a period of wage explosion in that country, captured by a dummy variable equal to 1.0 for 1973-74 and zero otherwise.

\subsection{Summary of the specification of the wage and price equations}

The preceding discussion suggests the following wage equation, in which the dependent variable is the rate of change of trend unit labor cost

$$
\begin{aligned}
w_{t}-\theta_{t}^{*}= & \alpha_{11} p_{t-1}+\alpha_{12} p_{t-2}+\alpha_{20} \hat{Q}_{t}+\alpha_{21} \hat{Q}_{t-1}+\alpha_{3}\left(p^{\mathrm{F}}-p\right)_{t} \\
& +\alpha_{4}\left(t^{\mathrm{T}}\right)_{t}+\alpha_{5} D_{t}^{\mathrm{WP}}+\delta_{0} D_{0 t}+\delta_{1} D_{1 t}+\delta_{2} D_{2 t} .
\end{aligned}
$$


Here $\hat{Q}_{t}$ is the log output ratio, $t_{t}^{\mathrm{T}}$ is the change in the total tax rate, $D_{t}^{\mathrm{WP}}$ is the wage push or controls dummy (1968-70 for Europe, 1973-74 for Japan, and 1971-72 reversed in 1974-75 for the U.S.), and the dummy variables designated $D_{i}$ measure the presence of excess real wage change for the periods $1964-84,1972-84$, and 1980-84. The inclusion of the lagged as well as current output ratio term allows the effect of aggregate demand to enter either as a level effect, rate of change effect, or both. In table 5 this specification of the wage change equation is estimated first with the $D_{i t}$ terms omitted and with the coefficients on the lagged price terms freely estimated, and then a second time with the $D_{i t}$ terms included and the constraint imposed that $\alpha_{11}+\alpha_{12}=1.0$.

The wage change equation is supplemented by an equation that explains changes in the value-added deflator, as in (13), which can be estimated in the straightforward form

$$
\begin{aligned}
p_{t}= & \beta_{10}\left(w-\theta^{*}\right)_{t}+\beta_{11}\left(w-\theta^{*}\right)_{t-1}+\beta_{20} \hat{Q}_{t}+\beta_{21} \hat{Q}_{t-1} \\
& +\beta_{3}\left(p^{\mathrm{F}}-p\right)_{t}+\beta_{4} t_{t}^{\mathrm{T}}+\beta_{5} D_{t}^{\mathrm{WP}}
\end{aligned}
$$

The wage-push/controls dummy variables are entered exactly as in the wage equations. In the case of Europe and Japan, the coefficient $\beta_{5}$ might be negative if an autonomous wage push squeezed profit margins, while in the U.S. the 1971-72 controls program applied to price markups as well as wage rates.

The final equation to be estimated is the reduced-form that results when (19) is substituted into (20). To simplify the presentation of the reduced form, the complex set of lagged coefficients is relabelled (e.g., $\gamma_{11}=\beta_{10} \alpha_{11}$ ), and several lagged terms that are indicated by the substitution are dropped to save degrees of freedom

$$
\begin{aligned}
p_{t}= & \gamma_{11} p_{t-1}+\gamma_{12} p_{t-2}+\gamma_{20} \hat{Q}_{t}+\gamma_{21} \hat{Q}_{t-1}+\gamma_{3}\left(p^{\mathrm{F}}-p\right)_{t} \\
& +\gamma_{4} t_{t}^{\mathrm{T}}+\gamma_{5} D_{t}^{\mathrm{WP}}+\delta_{0} D_{0 t}+\delta_{1} D_{1 t}+\delta_{2} D_{2 t}
\end{aligned}
$$

Notice that the productivity trend term $\left(\theta_{i}^{*}\right)$ drops out of the reduced-form, but included are the three dummy variables $\left(D_{i t}\right)$ that measure the presence of excess real wage change for the periods 1964-84, 1972-84, and 1980-84. The reduced-form price change equation (21) is estimated first with the $D_{i t}$ terms omitted and with the coefficients on the lagged price terms freely estimated, and then a second time with the $D_{i t}$ terms included and the 
constraint imposed that $\gamma_{11}+\gamma_{12}=1.0$. If any of the three $\delta_{i}$ coefficients are significantly positive, this would indicate that excess real wage change created an acceleration of inflation, and indirectly an increase in the natural rate of unemployment.

\section{Productivity growth and the real wage}

The specification of the wage and price mark-up equations contains a productivity trend growth term $\left(\theta^{*}\right)$ which must be estimated, in order to disentangle cyclical movements in productivity from trend movements. The cyclical productivity regressions developed in this section also allow us to assess the effect of real wage movements on the demand for labor and on labor's average product. A subsidiary purpose of this section is to assess the claim by Sachs that in Europe (but not in Japan) the overall effect of a sustained rise in unemployment is to raise productivity relative to trend' (1983, p. 281). His claim that labor productivity varies countercyclically in Europe contrasts with the standard assumption in the U.S. that productivity varies procyclically.

\subsection{Specification of the productivity equations}

The basic specification relates the $\log$ ratio of hours to trend output $\left(N_{t}-Q_{t}^{*}\right)$ to the $\log$ output ratio $\left(Q_{t}-Q_{t}^{*}\right)$, representing the cyclical effect of output on hiring decisions; to the real wage rate defined relative to the underlying productivity trend $\left[\left(W_{t}-P_{t}\right)-\Theta^{*} t\right]$, which could differ from zero as a result of excess growth in the real wage; and to the productivity trend itself $\left(\Theta_{t}^{*}\right)$. Taking this opportunity to redefine all upper-case letters as logs of levels, we can write

$$
\left(N_{t}-Q_{t}^{*}\right)=A+\phi\left(Q_{t}-Q_{t}^{*}\right)-\sigma\left(W_{t}-P_{t}-\Theta_{t}^{*}\right)-\Theta^{*} t
$$

where $A$ is a constant. Note that (22) is consistent with the labor demand function in (3), simply adding the cyclical effect to the normal static labor demand function in which labor hours depend on the real wage and laboraugmenting technical progress. As in (3), the trend in (22) picks up the effects of growth in the capital-labor ratio and of changes in other inputs.

When (22) is rewritten as an equation for the average product of labor $(Q / N)$, we can interpret the parameter $\phi$ as indicating the effect of cyclical movements in the output ratio on labor productivity

$$
\left(Q_{t}-N_{t}\right)=-A+(1-\phi)\left(Q_{t}-Q_{t}^{*}\right)+\sigma\left(W_{t}-P_{t}-\Theta^{*} t\right)+\Theta^{*} t
$$


If the parameter $\phi$ is unity, then a permanent increase in the output ratio has no impact on actual labor productivity, whereas a value of $\phi$ below unity implies a permanent productivity gain ('short-run increasing returns') and a value of $\phi$ above unity implies a permanent productivity loss ('short-run diminishing returns'). Thus the Sachs phenomenon of countercyclical productivity movements in Europe requires an estimated value of $\phi>1.0$.

\subsection{Theoretical and actual wage gap indexes}

We note that (23) allows us to define a wage gap concept adjusted not just for cyclical effects but for the endogenous response of productivity growth to excess growth in the real wage. The actual wage gap index $\left(W G_{t}\right)$ is $W-P-\Theta$ and the adjusted wage gap index $\left(W G_{t}^{*}\right)$ is $W-P-\Theta^{*} t$. Using these definitions, we can rearrange (23) to obtain

$$
W G_{t}=A-(1-\phi)\left(Q_{t}-Q_{t}^{*}\right)+(1-\sigma)\left(W G_{t}^{*}\right)
$$

This expression places an interesting perspective on the interrelationships between real wage behavior, productivity growth, and the wage gap index. If the elasticity of labor input with respect to the excess real wage $(\sigma)$ in (22) is unity, then (24) shows that the excess real wage growth 'pays for itself' by boosting actual productivity enough to keep the actual wage gap index $\left(W G_{t}=W_{t}-P_{t}-\Theta_{t}\right)$ unaffected. Only if the elasticity $(\sigma)$ is less than unity is excess real wage growth manifested in an increase in the observed actual wage gap index.

The actual wage gap index $\left(W G_{t}\right)$ for each of the three sectors in the U.S., Japan, and Europe without any adjustment for self-employment income is displayed in fig. 1. Because the actual wage gap is defined as the real product wage divided by labor's average product, the data displayed in fig. 1 can be interpreted simply as an index $(1972=1.0)$ of the share of employee compensation in value added. Three interesting features are worthy of notice in fig. 1 . First, in Europe the wage gap index increases relative to that in the U.S., and this feature of the data has been stressed by those authors who have advocated the hypothesis of classical unemployment in Europe. Second, this contrast between Europe and the U.S. is reversed after 1981 in the manufacturing sector; by 1984 the European manufacturing wage gap index had declined back to 1.0 , in contrast to a value of 1.07 for U.S. manufacturing Third, in each of the three sectors the wage gap index increased far more in Japan than in either Europe or the U.S., raising a question as to how an increase in the wage gap could be a sign of classical unemployment in 


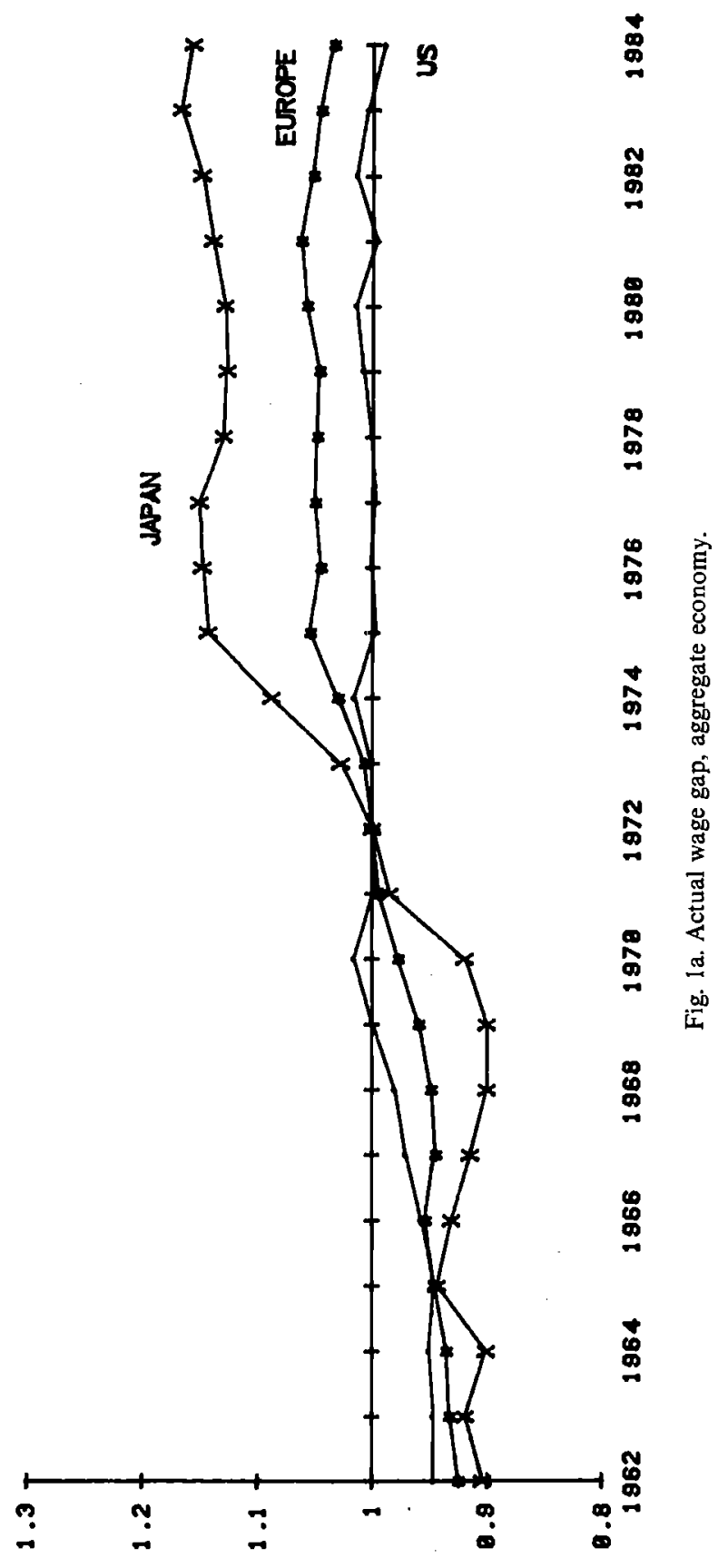




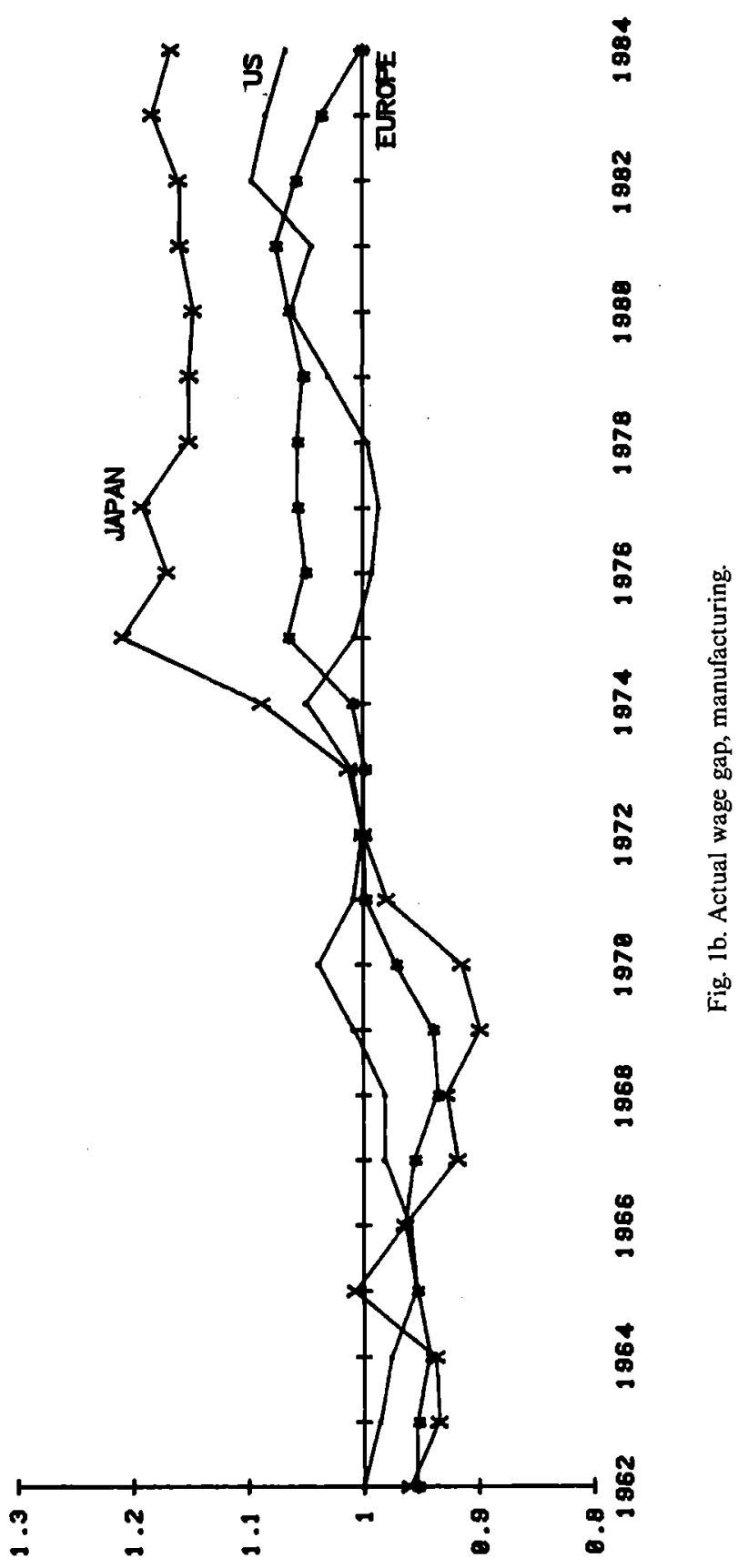




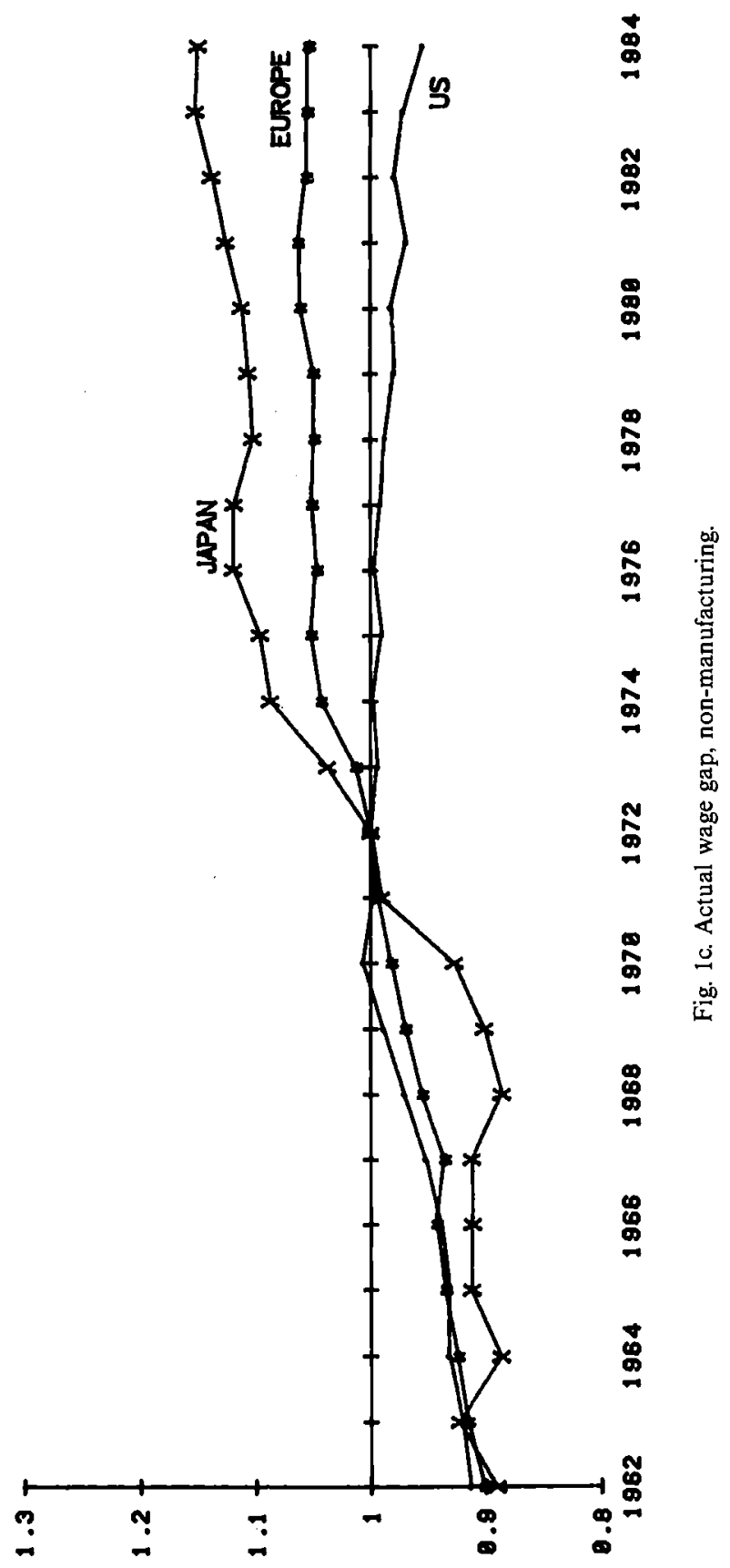


Europe, whereas an even larger increase in the wage gap in Japan did not cause the same phenomenon. ${ }^{9}$

The Japanese puzzle, as well as most of the contrast between Europe and the U.S., is eliminated by our inclusion of household entrepreneurial income with employee compensation as part of labor's income share. The difference made by the entrepreneurial income adjustment is displayed in fig. 2, where there is one frame for the aggregate sector in each of the three economies. While the difference made by the adjustment is small in the U.S., it makes a substantial difference for Europe and an even greater difference for Japan. With the adjustment, the values of the actual wage gap index for selected years are as in the table.

\begin{tabular}{rrrr}
\hline & U.S. & Japan & Europe \\
\hline 1964 & 98.0 & 101.0 & 98.5 \\
1972 & 100.0 & 100.0 & 100.0 \\
1975 & 98.7 & 107.6 & 102.8 \\
1979 & 99.3 & 104.5 & 100.2 \\
1984 & 94.9 & 100.7 & 97.0 \\
\hline
\end{tabular}

It is hard to see how the minor differences in these indexes could be responsible for the substantial differences among the three economies in the evolution of unemployment rates since the 1960s. Comparing 1964, 1972, and 1979, the U.S. and European wage gap indexes were basically identical, and the 1979-84 decline of 4.4 percent in the U.S. was only slightly greater than the 3.2 percent decline in Europe. The Japanese story seems to have been one of a jump in the wage gap index as a result of the 1973-74 wage push, followed by moderation that returned the index to its 1972 value by the early 1980s.

\subsection{Estimation of the labor input equations}

(22) could be estimated either in levels or in growth rates. Initial testing indicated that the growth rate specification is superior, avoiding the serial correlation that occurs with the level specification for some sectors. Allowing for lags and a post-1972 break in the productivity growth trend, (22) becomes

$$
\left(n-q^{*}\right)_{t}=\sum_{j=0}^{1} \phi_{j}\left(q-q_{*}\right)_{t-j}-\sum_{k=0}^{1} \sigma_{k}\left(w-p-\sum_{i=0}^{1} \theta_{i}^{*}\right)_{t-k}-\sum_{i=0}^{1} \theta_{i}^{*},
$$

\footnotetext{
${ }^{9}$ The Japanese anomaly cannot be explained away by disguised unemployment, since the annual growth rate of labor hours in the aggregate Japanese economy actually accelerated after 1979 when the wage gap index was at its highest (annual growth rates were 0.43 percent during 1960-72, 0.29 percent during 1972-79, and 0.86 percent during 1979-84).
} 


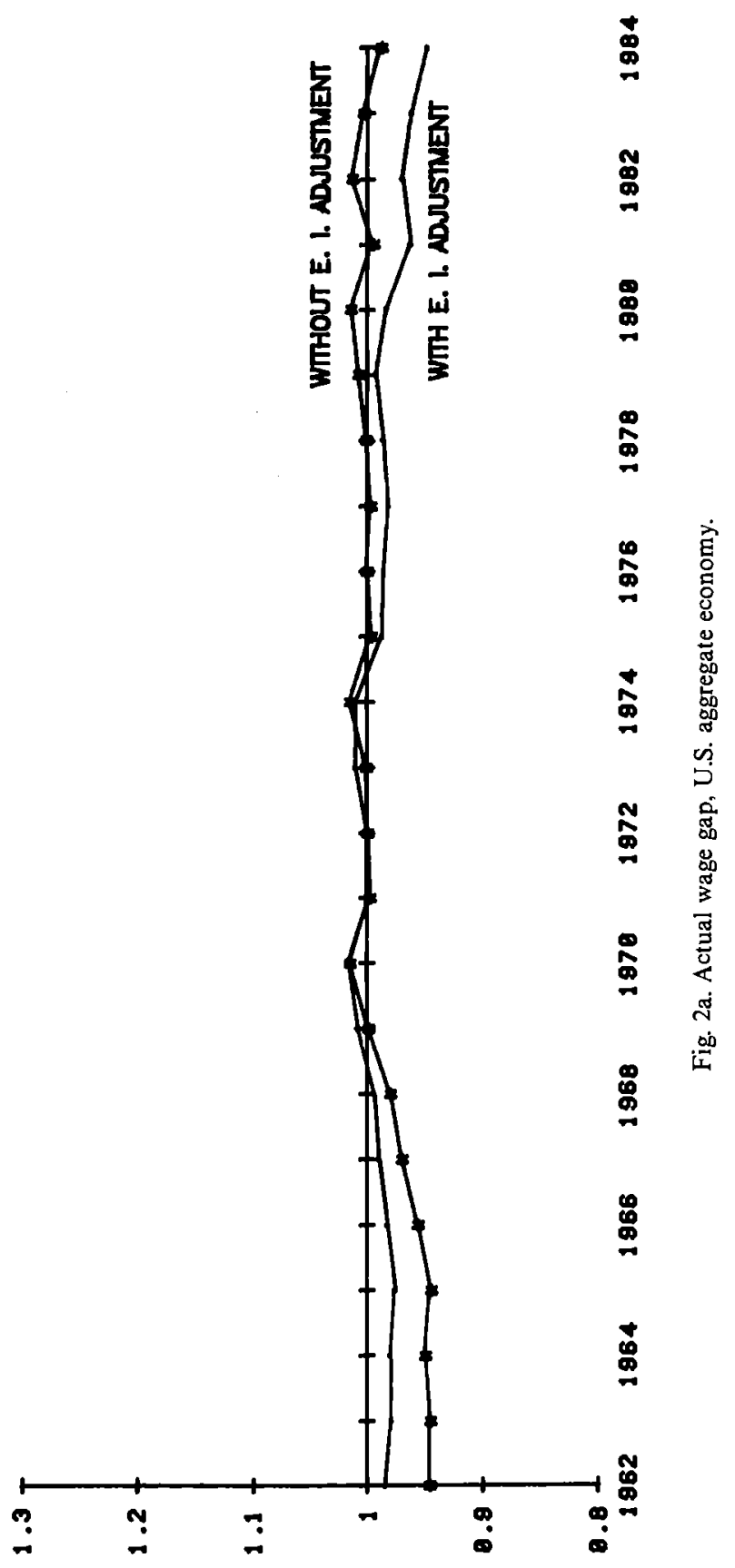




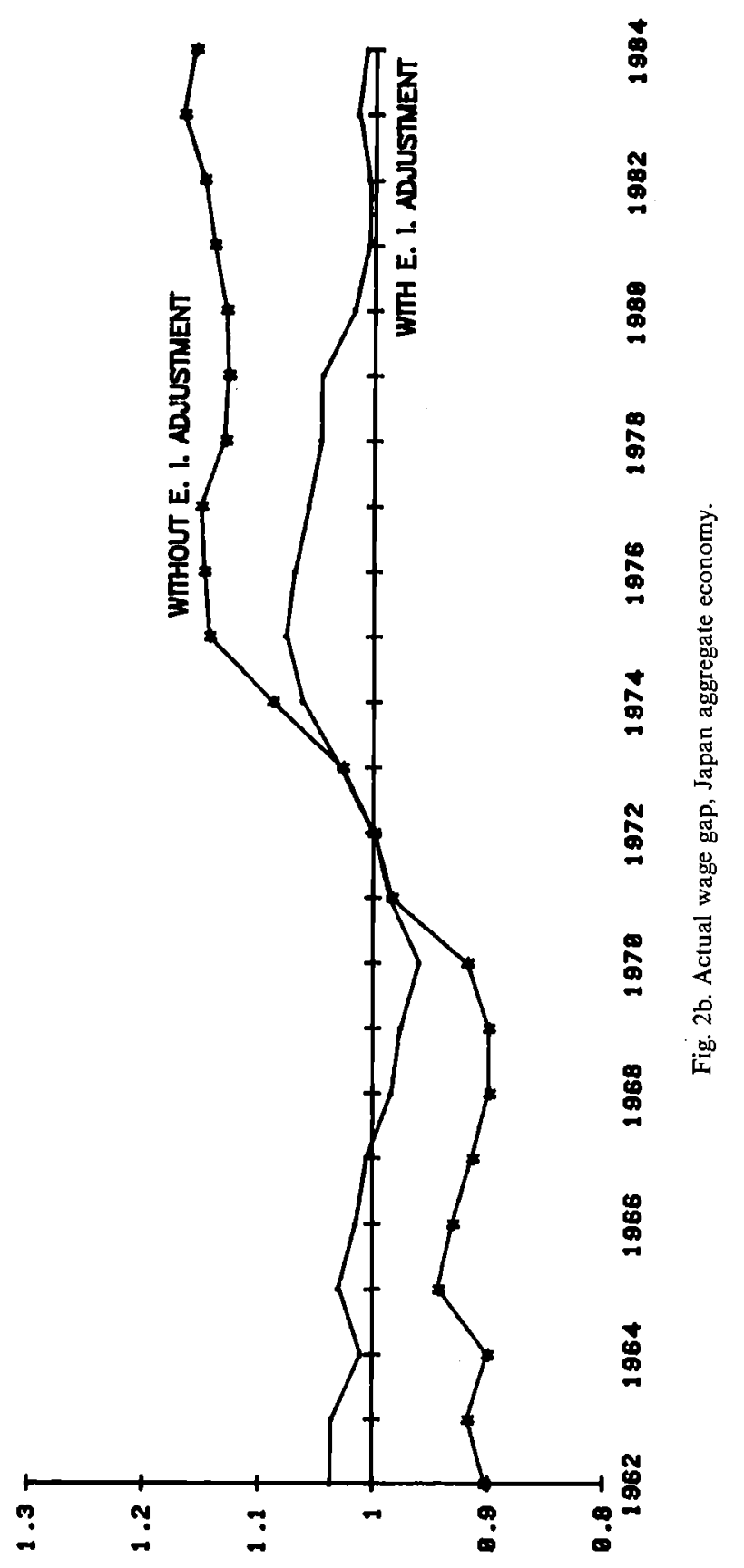




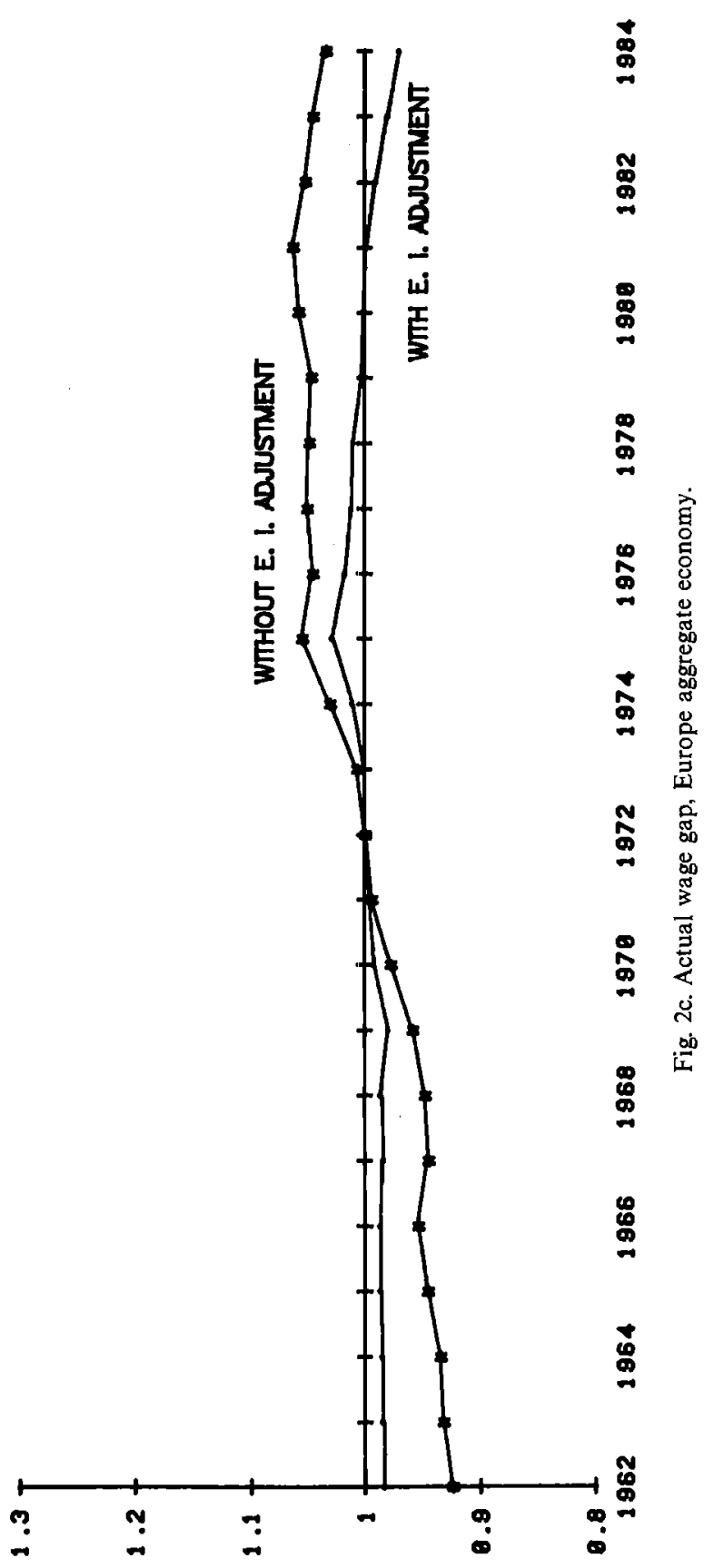


where $\theta_{0}^{*}$ is the $1964-72$ productivity trend and $\theta_{1}^{*}$ is the $1973-84$ productivity. trend. To unscramble the productivity trends from the estimated regression, run

$$
\left(n-q^{*}\right)_{t}=\sum_{j=0}^{1} \phi_{j}\left(q-q_{*}\right)_{t-j}-\sum_{k=0}^{1} \sigma_{k}(w-p)_{t-k}-\sum_{i=0}^{1} \alpha_{i}+\varepsilon_{t}
$$

where $\alpha_{0}$ is the constant term $(=1.01964-84)$ and $\alpha_{1}$ is a dummy variable $(=0 \quad 1964-72$ and $=1.01973-84)$. Then the productivity trend terms are defined as

$$
\theta_{0}^{*}=\frac{-\alpha_{0}}{1-\sum_{k} \sigma_{k}}, \quad \theta_{1}^{*}=\frac{-\left(\alpha_{0}-\alpha_{1}\right)}{1-\sum_{k} \sigma_{k}}
$$

In preliminary tests an additional productivity term $\left(\alpha_{2}=1.0\right.$ during 1980-84) was entered to test for the significance of a second growth slowdown after 1979 , but this term was uniformly insignificant in the presence of the real wage variable. With the real wage variable omitted, $\alpha_{2}$ was significant for the European aggregate and non-manufacturing sectors, as discussed below in connection with table 4 .

\subsection{Estimated productivity equations}

Results are presented in table 2 for the three sectors within the U.S., Japan, and Europe. All sums of coefficients on the output ratio are between zero and unity, indicating uniformly procyclical behavior of productivity, with U.S. manufacturing and European non-manufacturing closest to a neutral effect, and the Japanese aggregate indicating the greatest degree of labor hoarding (i.e., procyclical productivity response). An interesting result is that the labor hoarding phenomenon is more important in European non-manufacturing than in U.S. non-manufacturing.

The real wage elasticities are about one half in the non-manufacturing sectors of each country but are markedly lower in manufacturing, with a significant negative coefficient within manufacturing only for Europe. The aggregate real wage elasticity is about one-half in Japan and Europe and about one-third in the U.S. (although the U.S: coefficient is statistically insignificant). The productivity trend terms indicate extremely rapid rates of productivity growth in Japan prior to 1973 and very large slowdowns in the productivity growth trend in 1973-84, particularly in the aggregate and non-manufacturing. The U.S. productivity trend growth rates are so low as to be insignificantly different from zero in the aggregate and in non-manufacturing, and the U.S. post-1973 slowdown terms are insigificant in all three sectors. Europe is notable for having a post-1972 productivity trend in 
Table 2

Equations explaining annual change in hours relative to output growth $\left(n_{1}-q_{t}^{*}\right), 1964-84$.

\begin{tabular}{|c|c|c|c|c|c|c|c|}
\hline & \multicolumn{2}{|c|}{$\begin{array}{l}\text { Sum of coefficients } \\
\text { on current and one } \\
\text { lagged change in }\end{array}$} & \multicolumn{2}{|c|}{$\begin{array}{l}\text { Constant (trend) } \\
\text { terms }\end{array}$} & \multirow[b]{2}{*}{$\begin{array}{l}\bar{R}^{2} \\
(5)\end{array}$} & \multirow[b]{2}{*}{$\begin{array}{l}\text { S.E.E. } \\
(6)\end{array}$} & \multirow[b]{2}{*}{$\begin{array}{l}D .-W . \\
(7)\end{array}$} \\
\hline & $\begin{array}{l}\text { Output } \\
\text { ratio } \\
\text { (1) }\end{array}$ & $\begin{array}{l}\text { Real } \\
\text { wage } \\
\text { (2) }\end{array}$ & $\begin{array}{l}1964 \\
-1984 \\
(3)\end{array}$ & $\begin{array}{l}1973 \\
-1984 \\
(4)\end{array}$ & & & \\
\hline \multicolumn{8}{|l|}{ United States } \\
\hline $\begin{array}{l}\text { Aggregate } \\
\text { Manufacturing }\end{array}$ & $\begin{array}{l}0.91^{\mathrm{b}} \\
1.00^{\mathrm{b}}\end{array}$ & $\begin{array}{l}-0.33 \\
-0.36\end{array}$ & $\begin{array}{l}-2.02 \\
-2.66^{\mathrm{a}}\end{array}$ & $\begin{array}{l}0.98 \\
0.77\end{array}$ & $\begin{array}{l}0.82 \\
0.92\end{array}$ & $\begin{array}{l}0.78 \\
140\end{array}$ & $\begin{array}{l}2.21 \\
2.40\end{array}$ \\
\hline Non-manufacturing & $0.79^{\mathrm{b}}$ & $-0.53^{\mathrm{a}}$ & -1.42 & 0.02 & 0.66 & 0.73 & $\begin{array}{l}2.40 \\
1.82\end{array}$ \\
\hline \multicolumn{8}{|l|}{ Japan } \\
\hline Aggregate & $0.35^{\mathrm{a}}$ & $-0.48^{b}$ & $-8.76^{\mathrm{b}}$ & $5.30^{\mathrm{b}}$ & 0.90 & 0.92 & 2.35 \\
\hline Manufacturing & $0.53^{\mathrm{b}}$ & -0.14 & $-9.78^{b}$ & $3.21^{\mathrm{a}}$ & 0.71 & 1.95 & 2.21 \\
\hline Non-manufacturing & $0.56^{\mathrm{b}}$ & $-0.66^{\mathrm{b}}$ & $-7.66^{\mathrm{a}}$ & $6.80^{\mathrm{a}}$ & 0.85 & 1.62 & 2.25 \\
\hline \multicolumn{8}{|l|}{ Europe } \\
\hline Aggregate & $0.82^{\mathrm{b}}$ & $-0.54^{\mathrm{b}}$ & $-4.83^{\mathrm{b}}$ & $1.33^{\mathrm{a}}$ & 0.89 & 0.43 & 2.11 \\
\hline Manufacturing & $0.85^{\mathrm{b}}$ & $-0.26^{\mathrm{a}}$ & $-5.42^{\mathrm{b}}$ & $1.18^{\mathrm{a}}$ & 0.83 & 0.88 & 1.54 \\
\hline Non-manufacturing & $0.93^{b}$ & $-0.68^{b}$ & -3.85 & 0.91 & 0.83 & 0.49 & 1.44 \\
\hline
\end{tabular}

${ }^{a}$ Significant at 5 percent.

'Significant at 1 percent.

non-manufacturing higher than in both the U.S. and Japan, and in having a relatively slight slowdown in all three sectors.

Table 3 decomposes the change in productivity growth over three intervals among the effects of the estimated trend, the real wage, and cyclical movements in the output ratio. The total shown in columns (4), (8), and (12) refers is for the fitted value of the equations from table 2 . Recall that the post-1972 trend effect is the sum of columns (3) and (4) in table 2, with the signs reversed, as written out in eq. (27).

A novel aspect of these results concerns the non-manufacturing sectors of the U.S. and Japan. The U.S. displays no slowdown in trend productivity growth after 1972 in non-manufacturing, despite the slowdown evident in the raw data. This occurs because the equation explains almost all of the post1973 productivity growth slowdown as a response to a shift from positive excess real wage growth during 1964-72 to negative excess real wage growth in both periods after 1972. This effect of the time path of the real wage on U.S. productivity growth has received remarkably little discussion in the fruitless U.S. literature on the productivity slowdown puzzle. A similar phenomenon occurs in Japan, where real wage moderation after 1979 in non-manufacturing has the effect of cancelling out the positive post-1972 trend, leaving the fitted rate of productivity growth in non-manufacturing exactly zero for $1979-84$. 


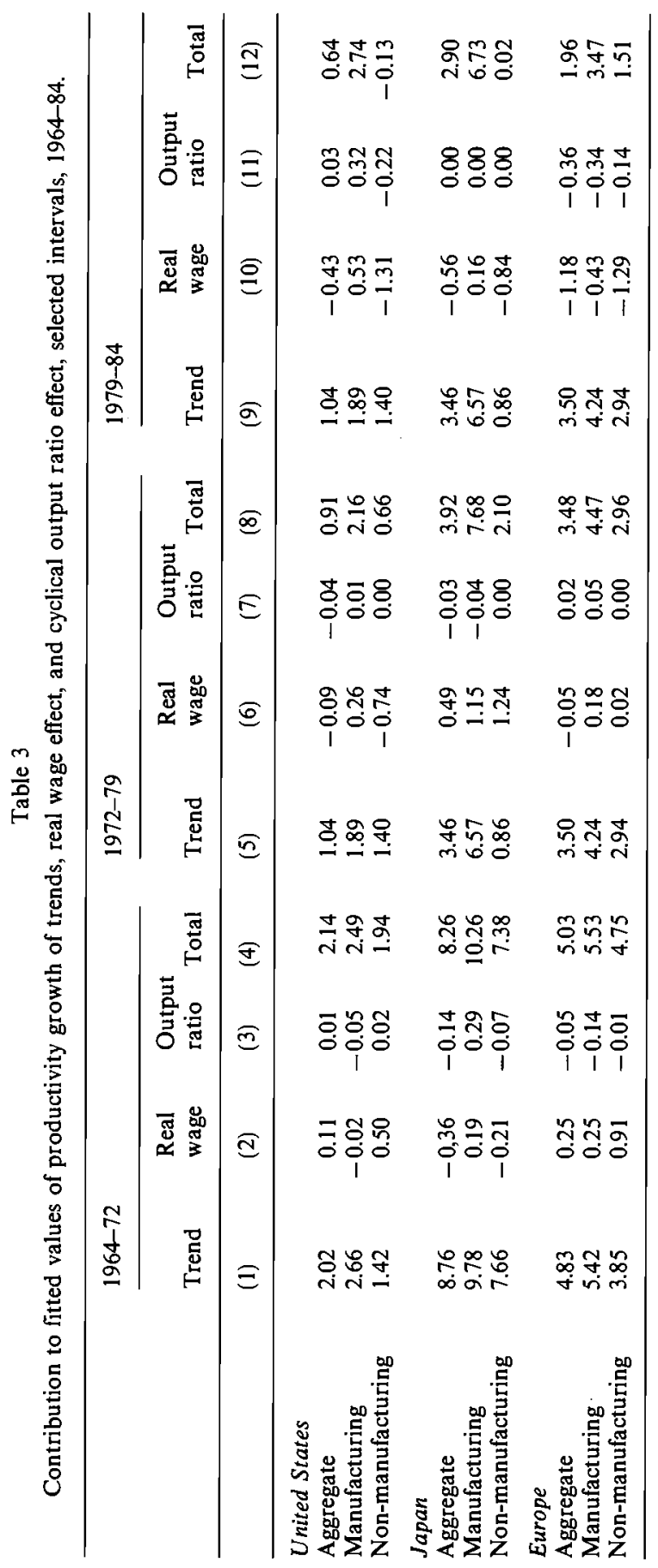


This approach attributes all of the slowdown in European productivity growth after 1979 to the real wage and cyclical effects, in roughly equal proportions in manufacturing, and with a larger role for real wage moderation in the aggregate and non-manufacturing sectors. The contrast between European and U.S. manufacturing during the $1979-84$ period is particularly striking, with U.S. manufacturing managing to achieve above-trend productivity growth as a result of excess real wage growth and a transitory cyclical effect (due to rapid output growth in 1983-4), while in European manufacturing actual productivity growth was below trend as a result of real wage moderation and a negative cyclical effect.

\subsection{Trends in output, productivity, and hours}

Table 4 brings together the assumed trend growth rates of output (based on the benchmark years 1961,1972, and 1979, as explained in section 3.2) with the estimated trend growth in productivity. Unlike those in table 3 , the productivity trends in table 4 are obtained from estimates of eq. (26) in which the real wage effects are omitted. These trends can be interpreted as incorporating a cyclical adjustment but no decomposition of the portion of the productivity trend attributable to real wage movements. When (26) is reestimated without the real wage variable, the third dummy variable representing the post-1979 slowdown becomes significant for the aggregate and non-manufacturing sectors of Europe (these regression results are omitted to save space).

The purpose of table 4 is to shed some light on the sources of the divergent movements of European unemployment rate from the unemployment rates of the U.S. and Japan. The counterpart of rising unemployment is, of course, slow or negative growth in labor hours. Obviously some part of the European unemployment problem results from output falling below trend, with $\log$ output ratios in Europe for 1984 of -8.5 percent for the aggregate, -11.1 percent for manufacturing, and -7.8 percent for non-manufacturing.

But it is also possible to look at the implications for labor hours of the underlying trends in output and productivity. Taken together, the output and productivity growth trends imply trends for labor input, shown in columns (3), (6), and (9) of table 4. Aggregate European trend hours fell in both periods before 1979 and actually rose slightly in the 1980s, but at a much slower rate than in the U.S. or Japan. However, the European aggregate disguises sharply divergent hours trends in manufacturing and non-manufacturing. The real European problem is low growth in manufacturing output in relation to a much higher rate of productivity growth. In non-manufacturing European trend hours growth on average since 1972 has been about equal to that in Japan. 


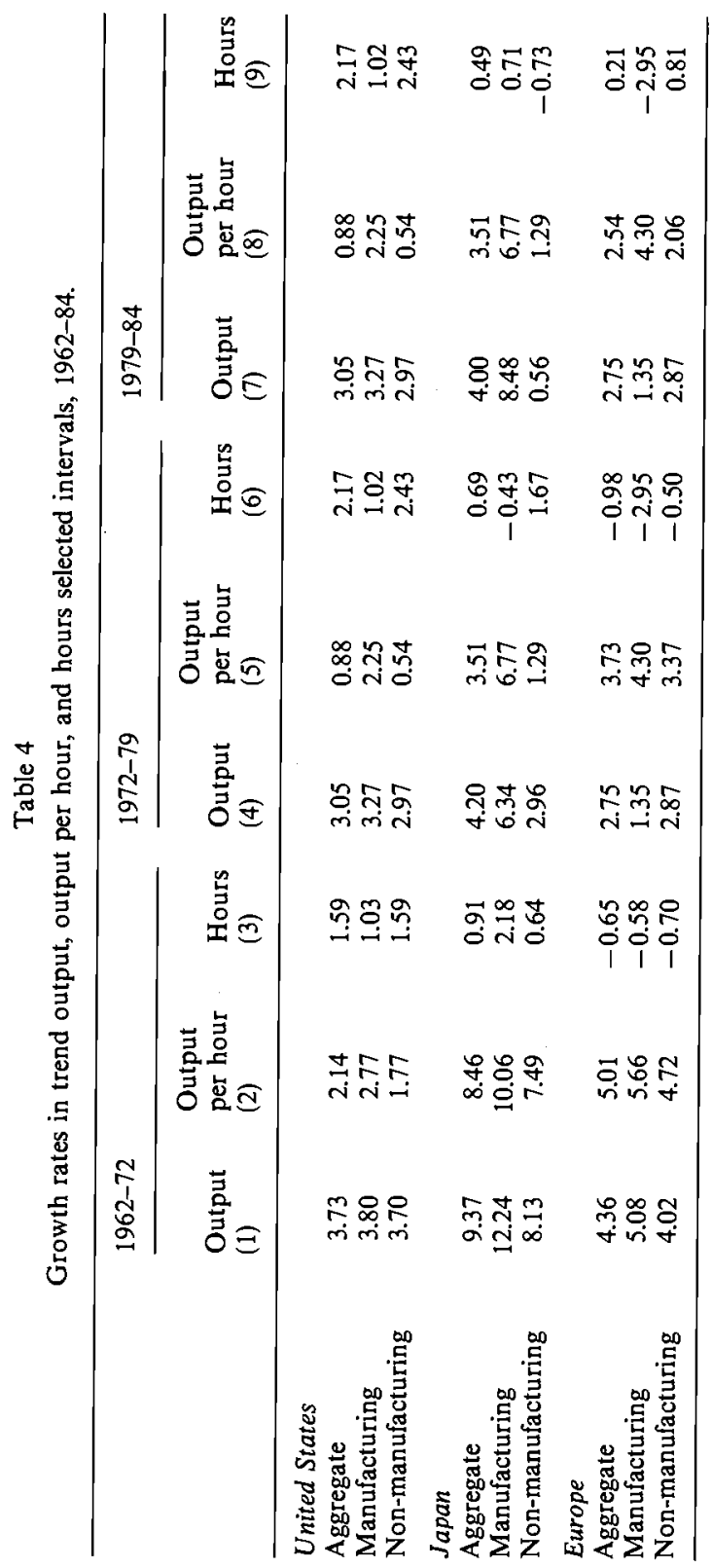


Table 4 places an interesting perspective on the U.S. phenomenon of rapid hours growth. Part of the U.S. difference from Europe stems from a lower decline in hours per employee (at a rate of about -0.25 percent per year as contrasted with -0.9 percent per year since 1972). However, most stems from faster employment growth. One can view the U.S. success in achieving rapid employment growth, however, as the counterpart of its dismal productivity record. One can calculate that if the U.S. had achieved the existing growth rate of output in 1979-84 but had combined it with European trend productivity growth, the U.S. would have had 8 percent fewer hours of labor input, or 9 million additional unemployed (ignoring effects on labor force participation and hours per employee).

\section{Estimated wage and price equations}

\subsection{Equations for wage change}

We now turn to estimates of the equation for wage change, specified as in (19) above in section 3.3. For variables where a string of lagged values is entered, only the sum of coefficients is exhibited in table 5 , as in table 2 above. Notes designate the significance of coefficients or sums of coefficients.

Two estimates of the wage equation are presented in table 5 for each sector within each country. The first omits the 'excess real wage growth' dummy variables and freely estimates the coefficients on lagged price change. The second includes the dummy variables and constrains the sum of coefficients on lagged price change to be unity, so the dependent variable is in the form of real wage growth adjusted for the estimated productivity trend.

We discuss first the results of the first version of the wage equation, presented as the first line of each pair. Some of the coefficients on lagged inflation are below unity and some are above. If 'excess real wage growth' occurs but no dummies are included, then the excess growth in the nominal wage rate relative to price change is likely to be picked up by a coefficient of greater than unity on the price change variable. This occurs in the U.S. aggregate and non-manufacturing, and in all three sectors for Europe.

The coefficients on the output ratio are generally positive and highly significant, supporting the Phillips curve hypothesis of a relation between the change in the wage rate and the level of a cyclical variable. Note that, because the current and one lagged output ratio term are included, the specification could reveal either a 'level effect' (a positive sum of coefficients) or a 'ra te of change effect' (a positive current coefficient followed by an equal and negative lagged coefficient, with a zero sum of coefficients). Only in U.S. manufacturing and Japanese non-manufacturing is the sum of coefficients insigificant in both versions of the wage equation, and in neither case does an insignificant sum of coefficients disguise a rate of change effect. 


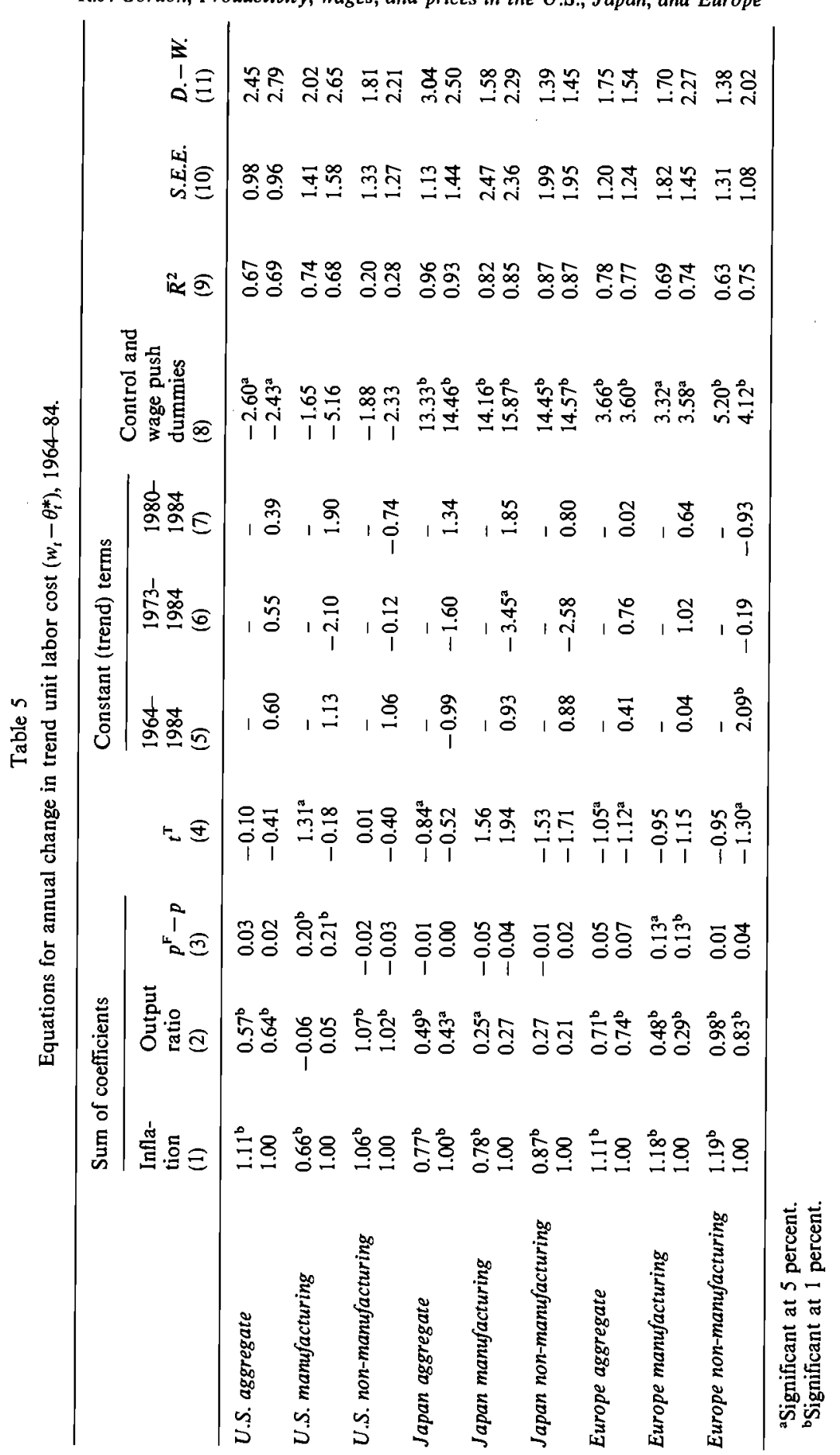


The sum of coefficients on the output ratio is an important indicator of nominal wage rigidity. The theme in the literature supporting a greater degree of wage rigidity in the U.S. than in Europe or Japan is supported here only for manufacturing. In non-manufacturing the output response of wage rates is actually greater in the U.S. than in either Japan or Europe, resulting in an aggregate response that is not appreciably smaller than in Europe and a bit greater than in Japan.

The wage equations also include the change in the real import price and in the total tax rate. The import price terms have the correct positive sign but are generally insignificant, except in U.S. and European manufacturing. The tax terms almost always have the incorrect (negative) sign, with a significant positive coefficient only in U.S. manufacturing, and significant negative coefficients in the Japanese and European aggregate equations. Thus these results deny the existence of a significant 'tax push' effect that is responsible for driving up real wage rates and in this sense conflict with the hypothesis advanced by Tullio (1987) in this volume and with results of Knoester and van der Windt (1985).

Turning now to the coefficients displayed in column (8) of table 5 , the wage push dummy variables for Japan and Europe have large and significant coefficients. As an example, the coefficient for the Japanese aggregate economy indicates that in 1973-74 wage rates increased 13 percent more per year than can be explained by the other variables, and for Europe in 1968-70 wage rates increased 3.6 percent more per year than the other variables can explain. The wage controls dummy variables are significant for the U.S. aggregate economy, but not for manufacturing and non-manufacturing separately.

The second line of each pair of results displays a version of the wage equation in which the sum of coefficients on lagged inflation is constrained to be unity, and the 'excess real wage growth' dummy variables are included [see columns (5), (6), and (7)]. These coefficients are almost all insignificant, except for a large negative coefficient in Japanese manufacturing after 1972, and a positive coefficient in European non-manufacturing for the entire period. Of particular importance are the small and uniformly insignificant set of excess real wage growth dummy variables for the European aggregate economy and for the manufacturing sector, denying the importance of real wage rigidity, and calling attention instead to the wage push during 1968-70 (column 8) as the sole source of a 'real wage problem' in Europe. Also important for the interpretation of the European unemployment problem is the absence of a significantly positive coefficient for $1980-84$, as would be required to confirm the hypothesis that high unemployment in Europe did not hold down wage changes as much as would have been predicted from pre-1980 behavior. The interpretation of the $1980-84$ period receives more attention in our discussion of the 'hysteresis' hypothesis below. 


\subsection{Mark-up price equations}

To complete the estimation of the wage-price model, table 6 reports estimates of the price mark-up equation in the form (20) above. To review, the mark-up equation is specified in first difference form. The inflation rate is regressed on the change in trend unit labor cost (current and one lag), the output ratio (current and one lag), the current rate of change of relative import prices, the two-year change in the total tax rate, and the single dummy variable for wage push or controls. To validate the original theoretical specification in (13), the output ratio should enter as a first difference, that is, the coefficient on the current output ratio should be positive and on the lagged output ratio should be equal in absolute value and negative in sign.

The results appear to contradict the hypothesis of a procyclical price markup. Of the nine lines in table 6 , seven indicate a negative sum of coefficients on the output ratio (with four of the seven sums significant), indicating a perverse Phillips curve phenomenon that offsets part of the positive Phillips curve effect in the wage change equations. This can be interpreted as suggesting that in an open economy in which competition from abroad limits the short-run flexibility of prices, a demand expansion that raises the output ratio and the rate of wage change is reflected only partly in price change, resulting in a positive growth rate of the real wage. Such a result implies procyclical rather than countercyclical real wage behavior, but refers to the rate of change of the real wage rather than its level. Five sums of coefficients in column (2) of table 6 are insigificantly different from zero, and in no case does this reflect any significant zig-zag from a positive to a negative coefficient, as would be implied by a rate-ofchange effect of the business cycle on the change in the markup.

The other coefficients in table 6 imply that the elasticity of price change to the change in trend unit labor cost is close to unity within the current and subsequent year. Import price changes are insignificant, except in the nonmanufacturing sector for the U.S. A positive and significant tax push effect occurs only for the Japanese aggregate economy. Finally, the wagepush and controls dummies are uniformly insignificant, indicating that for Japan and Europe the wage-push episodes raised wages but did not squeeze profits, leaving the markup unaffected.

\subsection{Reduced-form inflation equations}

Together the wage and price mark-up equations imply the reduced-form equation for price change written above as (21). This relates the current inflation rate to two lags of the inflation rate, the current and lagged output ratio, the current change in the import price, the two-year change in the tax 


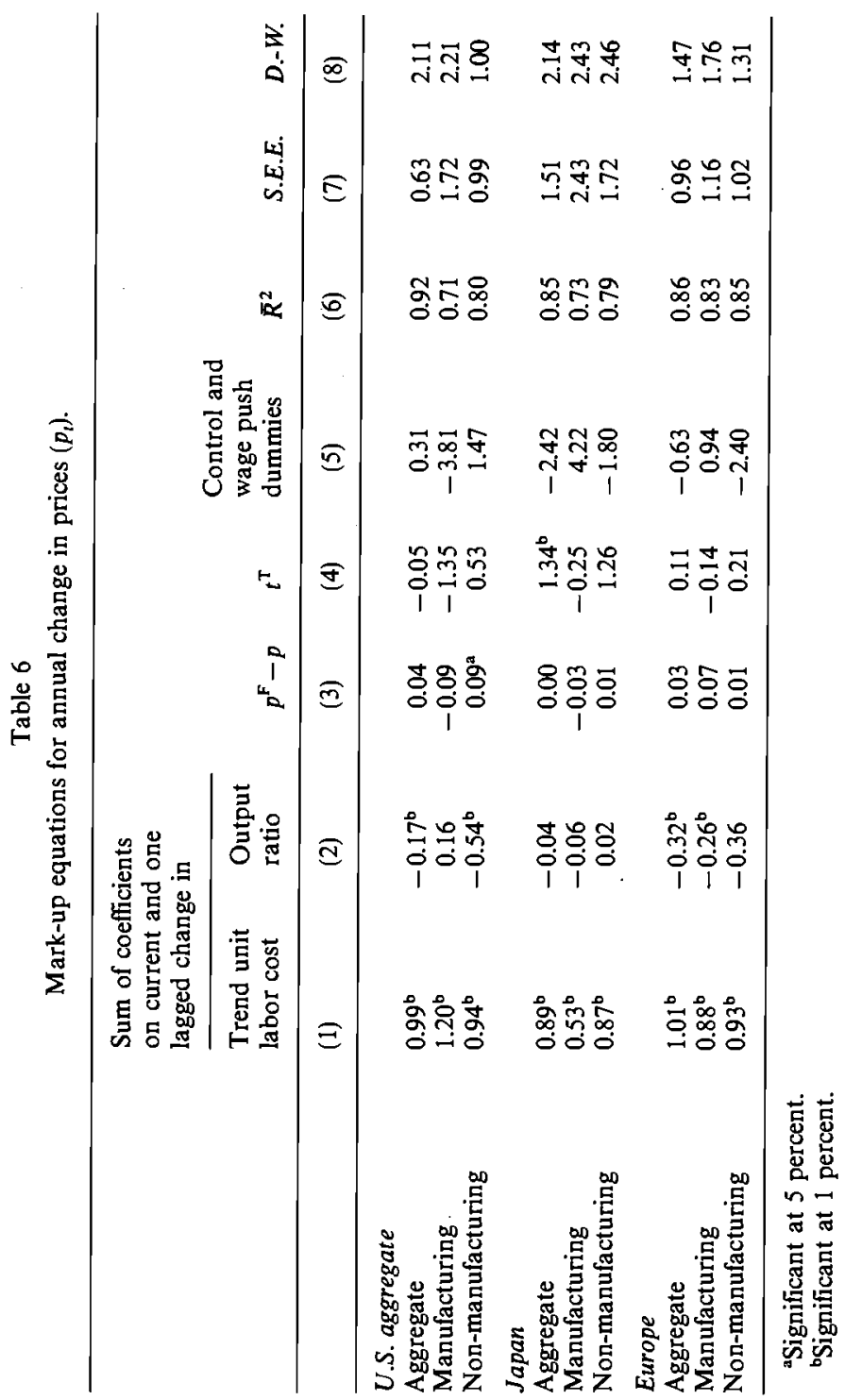


rate, and the same wage-push and control dummies discussed before. Table 7 presents the results of estimating (21).

The reduced-form equation is critical for determining the overall nominal flexibility of an economy. Flexibility in the form of a high positive coefficient on the output ratio in the wage change equation means little if it is offset by a high negative coefficient on the output ratio in the price mark-up equation. Column (2) of table 7 indicates that there are significant Phillips curve effects of the level of the output ratio in the reduced-form inflation equation in six of the nine sectors. Only in U.S. manufacturing and in both Japanese disaggregated sectors is there no significant Phillips curve effect. At the aggregate level the sum of coefficients on the output ratio is significant for all three economies in the relatively narrow range of 0.30 for the U.S., 0.37 for Europe, and 0.45 for Japan. Thus table 7 conflicts with previous claims that Europe exhibits significantly greater nominal flexibility than the U.S. Table 7 confirms the verdict of table 5 that nominal rigidity is limited to U.S. manufacturing, but nominal flexibility in U.S. non-manufacturing is almost as great as in European non-manufacturing.

The other coefficients displayed in table 7 can be compared with the parallel coefficients in table 5 for the wage change equations. The coefficients on the relative import price change term are all significantly positive for the aggregate and manufacturing sectors of the U.S. and Europe and are of plausible magnitudes. The insignificance of the import price coefficients for Japan may reflect the much-discussed absence of manufactured imports and of an import-competing sector.

The estimated controls coefficients in column (8) for the U.S. aggregate economy are similar to but less significant than those in my recent paper (1985) on the behavior of the U.S. inflation rate in quarterly data. For Japan the 1973-74 wage-push phenomenon was almost entirely reflected in faster inflation in the manufacturing sector, while in non-manufacturing about onequarter of the 'push' was not reflected in faster inflation but rather (implicitly) in a profit squeeze. As for Europe, the reduced-form coefficients imply a significant acceleration of inflation in 1968-70 which was roughly equal to the magnitude of the wage-push effect in the wage equation.

\subsection{The output sacrifice ratio}

A useful measure of an economy's nominal rigidity is its 'output sacrifice ratio', a concept originally applied to a hypothetical reduction in nominal GNP growth intended permanently to slow the rate of inflation. The ratio is defined as the cumulative output loss (expressed as a percent of one year's GNP) following a hypothetical nominal GNP deceleration, divided by the permanent reduction in the inflation rate which is achieved. For instance, the U.S. disinflation of the 1980s can be described as involving (roughly) a five 


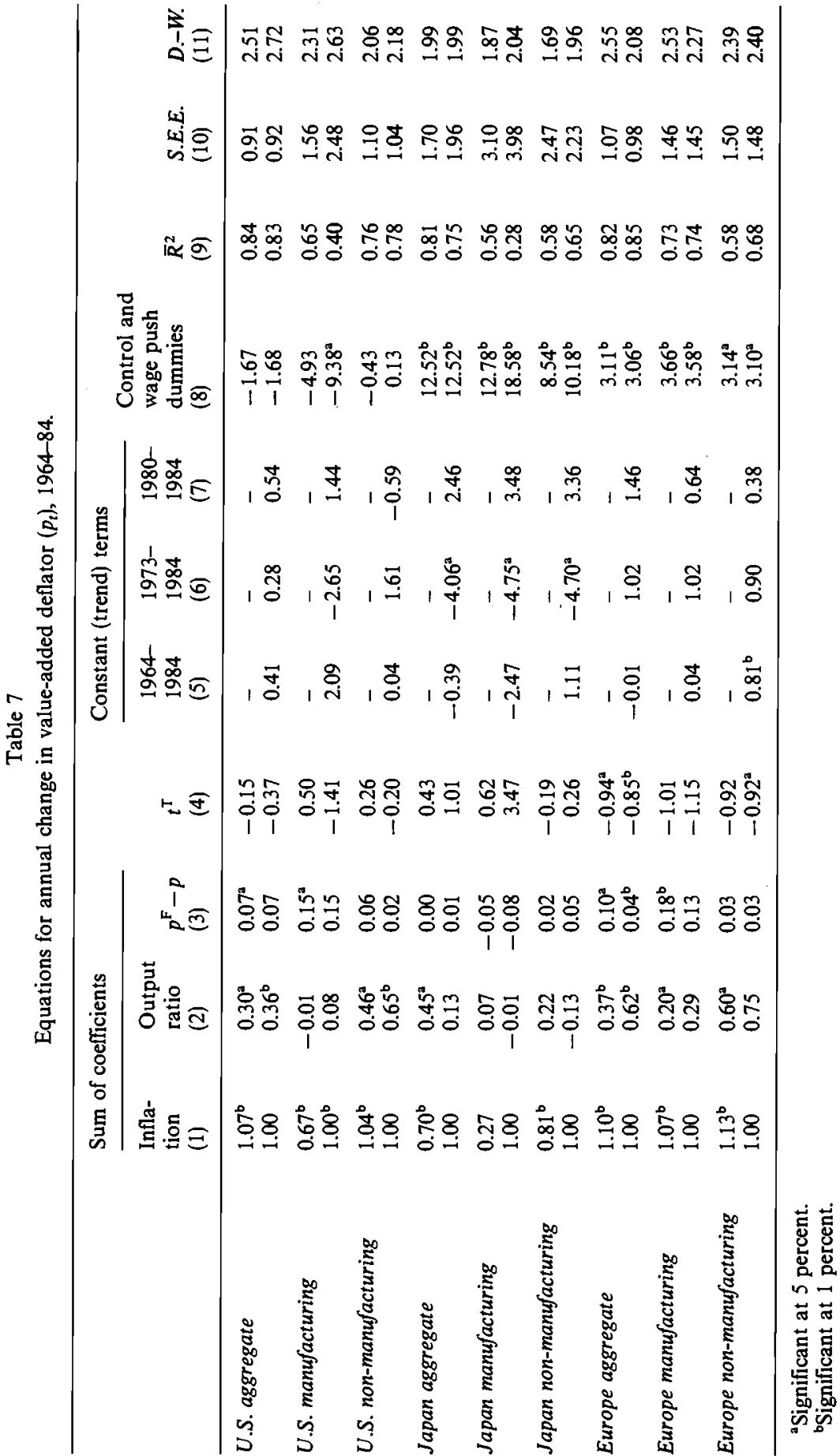


percent permanent reduction in nominal GNP growth, a five percent permanent reduction of the inflation rate, and a cumulative output loss equal to 30 percent of a year's GNP, for an output sacrifice ratio of $6.0(=30 / 5)$.

Of course the sacrifice ratio concept can be applied in reverse to the issue of reflation. Starting from a situation of a low output ratio and low inflation, how much output would be gained from an acceleration of nominal GNP growth, and at what cost in the form of permanently higher inflation? The wage-price model developed in this paper can be simulated to calculate the sacrifice ratio implied by the estimated coefficients. When the reduced-form equations of table 7 are used, the simulations are particularly straightforward, consisting of a two-equation model. The first equation is the reducedform equation relating inflation to lagged inflation and the current and lagged output ratio (the relative import price change, tax change, and wagepush dummy variables are all set to zero). The sum of coefficients on lagged inflation is constrained to sum to unity, and no other dummy variables or constants are included. The second equation is the identity that defines this year's $\log$ output ratio as equal to last year's ratio, plus the current growth rate of nominal GNP, minus the current inflation rate, minus the growth rate of natural (i.e., trend) real GNP.

The simulations are calculated for the 20-year period from 1985 to 2004. The growth rate of nominal GNP is initially set at the growth rate of natural real GNP plus the 1984 inflation rate, and the two-equation model is simulated to determine the output ratio and inflation rate over the 20-year period when the growth rate of nominal GNP is set permanently at this initial level. Then an alternative simulation is run in which growth rate of nominal GNP is set permanently at a rate 5 percent higher than the initial level.

Table 8 exhibits the average inflation rates over the 20 year period in each simulation, the cumulative values of the output ratio, and the implied output sacrifice ratio. The line labelled 'reduced form' describes the experiment described above, and the line labelled 'wage-price model' describes the analogous experiment using a three-equation model consisting of the wage equation from table 5 , the price mark-up equation from table 6 , and the identity defining the current output ratio.

It is important to note that these simulations maintain at zero the changes in the relative import price terms that enter into the wage and price equations. Thus the expansion of nominal GNP growth is implicitly assumed to take the form of a mixed monetary and fiscal policy stimulus that maintains the value of the real exchange rate. Sacrifice ratios calculated for a monetary expansion with the exchange rate endogenous tend to yield a smaller output sacrifice, since the exchange rate depreciation resulting from a monetary stimulus would tend to accelerate inflation faster and reduce the remaining amount of the extra nominal GNP growth available to support real output growth. 
Table 8

Output sacrifice ratios based on a permanent acceleration of nominal GNP by 5.0 percent compared to a 'before' simulation.

\begin{tabular}{|c|c|c|c|c|c|}
\hline & \multicolumn{2}{|c|}{ Averages, 1985-2004 } & \multirow{2}{*}{\multicolumn{2}{|c|}{$\begin{array}{l}\text { Cumulative } \\
\text { output ratio to } 2004\end{array}$}} & \multirow{3}{*}{$\begin{array}{l}\text { Output } \\
\text { sacrifice } \\
\text { ratio } \\
\text { (5) }\end{array}$} \\
\hline & \multirow{2}{*}{$\begin{array}{l}\text { Inflation } \\
\text { 'Before' } \\
\text { (1) }\end{array}$} & \multirow{2}{*}{$\begin{array}{l}\text { Inflation } \\
\text { 'After' } \\
(2)\end{array}$} & & & \\
\hline & & & $\begin{array}{l}\text { 'Before' } \\
\text { (3) }\end{array}$ & $\begin{array}{l}\text { 'After' } \\
\text { (4) }\end{array}$ & \\
\hline \multicolumn{6}{|l|}{ U.S. } \\
\hline Reduced-form & 3.2 & 8.0 & 0.1 & 31.5 & 6.5 \\
\hline Wage-price model & 3.2 & 8.0 & -1.2 & 30.9 & 6.6 \\
\hline \multicolumn{6}{|l|}{ Japan } \\
\hline Reduced-form & 0.6 & 5.6 & -0.1 & 11.4 & 2.3 \\
\hline Wage-price model & 0.6 & 5.6 & 0.1 & 11.5 & 2.3 \\
\hline \multicolumn{6}{|l|}{ Europe } \\
\hline Reduced-form & 4.7 & 10.1 & 24.6 & 50.3 & 4.8 \\
\hline Wage-price model & 2.6 & 7.9 & -11.5 & 60.2 & 13.5 \\
\hline
\end{tabular}

The sacrifice ratios displayed in table 8 for the U.S. are 6.5 for the reduced-form inflation equation and 6.6 for the separate wage and markup equations. These compare to sacrifice ratios in Gordon (1985) of about 8 with no import price feedback, and of about 4.5 with an endogenous foreign price feedback. As might be expected, the sacrifice ratios for Japan are much smaller than for the U.S. Finally, the sacrifice ratio implied by the reduced form equation for Europe is 4.8, only moderately below that for the U.S., and for the separate wage and markup equations is actually 13.5, much higher than that for the U.S. ${ }^{10}$

\subsection{The 'hysteresis' hypothesis}

The last topic of the paper is the 'hysteresis' hypothesis, which states that the natural rate of unemployment is 'path dependent', that is, is not independent of the evolution of the actual unemployment rate but rather responds with a lag to the path fo the actual unemployment rate. In this paper, which focusses on the equivalent concepts of the natural level of output and the log output ratio, the hysteresis hypothesis states that the natural level of output evolves not along a log-linear trend but with a lagged response to the actual path of output. If valid, this hypothesis would have

\footnotetext{
${ }^{10}$ The wage-markup model for Europe is prone to oscillations, due to the fact that virtually the entire positive cyclical effect of the output ratio on the rate of wage change occurs with a one-year lag. The results displayed in table 8 were obtained by constraining the current and oneyear lagged coefficients on the output ratio to be equal. This constraint reduces the sum of coefficients on the output ratio only from 0.62 to 0.56 and raises the standard error of the estimated equation only from 1.25 to 1.28 .
} 
the important policy implication that the output slump in Europe in the 1980 s has reduced the natural level of output, gradually eliminating slack to the point that there is no longer any further downward pressure on wage changes. ${ }^{11}$

Out test of the hysteresis approach can be illustrated in a simplified version of the wage equation included here for expository purposes only

$$
\begin{aligned}
w_{t}-p_{t-1} & =\alpha_{0}+\alpha_{11}\left(Q_{1}-Q_{t}^{*}\right)+\alpha_{12}\left(Q_{t-1}-Q_{t-1}^{*}\right) \\
& =\alpha_{0}+\alpha_{11} \Delta\left(Q_{t}-Q_{t}^{*}\right)+\left(\alpha_{11}+\alpha_{12}\right)\left(Q_{t-1}-Q_{t-1}^{*}\right),
\end{aligned}
$$

where once again upper-case letters designate logs of levels, and both the current and one lagged value of the output ratio are included in the wage equation to accord with our basic specification reported in table 5. The second line of (28) restates the role of the output ratio as entering through the current difference $(\Delta)$ and the lagged level.

Let us assume that the unobservable natural output level $\left(Q_{t}^{*}\right)$ is some unknown weighted average of the linear trends of table $3\left(Q_{t}^{\mathrm{T}}\right)$ and a hysteresis term $\left(Q_{t}^{\mathrm{H}}\right)$ equal to a three-year moving average of actual output

$$
Q_{t}^{*}=\Psi Q_{t}^{\mathrm{H}}+(1-\Psi) Q_{t}^{\mathrm{T}}
$$

To identify the $\Psi$ parameter, we substitute (29) into the lagged level term (28), while assuming that in the difference term $Q_{t}^{*}=Q_{t}^{\mathrm{T}}$. Rearranging, we obtain

$$
\begin{aligned}
w_{t}-p_{t-1}= & \alpha_{0}+\alpha_{11} \Delta\left(Q_{t}-Q_{t}^{\mathrm{T}}\right)+\left(\alpha_{11}+\alpha_{12}\right)\left(Q_{t-1}-Q_{t-1}^{\mathrm{T}}\right) \\
& -\left(\alpha_{11}+\alpha_{12}\right) \Psi\left(Q_{t-1}^{\mathrm{H}}-Q_{t-1}^{\mathrm{T}}\right)
\end{aligned}
$$

The hysteresis coefficients $(\Psi)$ listed in table 9 are obtained by running the wage change equations from table 5 and the reduced-form change equations from table 7 again with the addition of the lagged $\left(Q_{t}^{\mathrm{H}}-Q_{t}^{\mathrm{T}}\right)$ term, where $Q_{t}^{\mathrm{H}}$ is defined as a trend-adjusted three-year moving average

$$
Q_{t}^{\mathrm{H}}=\left[Q_{t}+\left(1+q_{t-1}^{\mathrm{T}}\right)\left(Q_{t-1}+\left(1+2 q_{t-2}^{\mathrm{T}}\right) Q_{t-1}\right] / 3\right.
$$

where a lower-case $q^{T}$ refers to the growth rate of the output trend for the year in question. The most important finding in table 9 is that the hysteresis coefficients are insignificant for the wage change equation, except in U.S. and

\footnotetext{
${ }^{11}$ Empirical evidence supporting the hysteresis hypothesis for Europe is presented by Blanchard and Summers (1986) and for France by Sachs and Wyplosz (1985). Policy implications are analyzed by Sachs (1986).
} 
Table 9

'Hysteresis' coefficients in reduced-form price equation and in wage equation.

\begin{tabular}{|c|c|c|c|c|}
\hline & \multicolumn{2}{|c|}{ Wage equation } & \multicolumn{2}{|c|}{$\begin{array}{l}\text { Reduced-form } \\
\text { price equation }\end{array}$} \\
\hline & $\Psi$ Coefficient & [ $t$ ratio] & $\Psi$ Coefficient & [ $t$ ratio] \\
\hline \multicolumn{5}{|l|}{ U.S. } \\
\hline Aggregate & 0.40 & {$[1.50]$} & 0.51 & [1.09] \\
\hline Manufacturing & 2.66 & {$[1.98]$} & 1.38 & {$[0.96]$} \\
\hline Non-manufacturing & 0.30 & {$[0.99]$} & 0.88 & {$[2.56]$} \\
\hline \multicolumn{5}{|l|}{ Japan } \\
\hline Aggregate & 0.11 & {$[0.30]$} & 0.80 & [2.11] \\
\hline Manufacturing & 0.79 & [3.41] & 1.16 & {$[1.65]$} \\
\hline Non-manufacturing & 0.33 & {$[0.54]$} & 0.92 & {$[1.80]$} \\
\hline \multicolumn{5}{|l|}{ Europe } \\
\hline Aggregate & -0.12 & {$[-0.11]$} & 0.81 & {$[1.13]$} \\
\hline Manufacturing & -0.15 & {$[-0.16]$} & -0.77 & {$[-0.30]$} \\
\hline Non-manufacturing & 0.53 & {$[-0.67]$} & 0.94 & {$[1.06]$} \\
\hline
\end{tabular}

Japanese manufacturing, and in the reduced-form price change equation except in U.S. non-manufacturing and the Japanese aggregate sectors. In Europe, where the problem of high unemployment stimulated the development of the hysteresis hypothesis, the $\Psi$ coefficients are uniformly insignificant.

Because the statistical insignificance of the hysteresis effect for Europe conflicts with most of the recent literature, particularly Blanchard and Summers (1986) and Sachs (1986), we have conducted further tests to assess its importance. First, we display four time series for the European aggregate covering the period $1979-84$, including the $\log$ output ratio defined alternatively relative to the $1072-84$ trend $\left(Q_{t}-Q_{t}^{\mathrm{T}}\right)$ and relative to the hysteresis concept of the natural rate $\left(Q_{t}-Q_{t}^{\mathrm{H}}\right)$, as well as the dependent variables of the price change $\left(p_{t}\right)$ and wage change $\left(w_{t}-\theta_{t}\right)$ equations.

\begin{tabular}{lccrc}
\hline & $Q_{1}-Q_{i}^{\mathbf{T}}$ & $Q_{1}-Q_{1}^{\mathrm{H}}$ & \multicolumn{1}{c}{$p_{t}$} & $w_{t}-\theta_{\boldsymbol{t}}$ \\
\hline 1979 & 0.09 & 0.64 & 7.77 & 6.44 \\
1980 & -1.40 & -0.68 & 10.31 & 7.97 \\
1981 & -4.24 & -2.34 & 9.10 & 7.62 \\
1982 & -6.50 & -2.41 & 8.87 & 6.47 \\
1983 & -7.91 & -1.64 & 6.76 & 4.71 \\
1984 & -8.51 & -0.81 & 5.28 & 2.60 \\
\hline
\end{tabular}

Thus the hysteresis version of the log output ratio in the second column indicates that slack in Europe had almost disappeared by 1984, in contrast to the GNP gap of 8.5 percent implied by the output ratio measured relative to the $1972-84$ trend. 
Since the estimated hysteresis coefficients in table 9 do not provide a statistically significant measure of the hysteresis coefficient $(\Psi)$ for Europe, another alternative is to estimate separate wage change and reduced-form price equations using the two concepts of the log output ratio $\left(Q_{t}-Q_{t}^{\mathrm{T}}\right.$ and $\left.Q_{t}-Q_{t}^{H}\right)$ as alternatives. The standard errors for the alternative equations for the European aggregate economy are

\begin{tabular}{lll}
\hline & $p_{1}$ & $w_{t}-\theta_{t}$ \\
\hline Using $Q_{t}-Q_{t}^{T}$ & 1.07 & 1.20 \\
Using $Q_{t}-Q_{t}^{\text {H }}$ & 1.03 & 1.56 \\
\hline
\end{tabular}

The first line corresponds precisely to the unconstrained results for the European aggregate economy in tables 7 and 5, respectively. The second line uses the alternative hysteresis concept of the output ratio $\left(Q_{t}-Q_{t}^{\mathbf{H}}\right.$ in place of $Q_{t}-Q_{1}^{\mathrm{T}}$ ) for the full 1964-84 period. The results indicate a mixed verdict. The hysteresis version fo the $\log$ output ratio performs slightly better in the reduced-form price change equation but much worse in the wage change equation. Since most theoretical justifications of the hysteresis concept are based on labor market behavior and the presumed failure of wage rates to adjust to labor market slack, these results raise serious questions about the validity of the hysteresis hypothesis for Europe in the 1980s. ${ }^{12}$

What is the implied natural rate of unemployment for Europe predicted by our concept of the log output ratio based on the 1972-84 output trend? To calculate this implication of the results, an Okun's Law equation was estimated for 1964-79 which regresses the unemployment gap (defined relative to an assumed natural rate of unemployment series linearly interpolated between the actual values of 1961, 1972, and 1979) on the current and one lagged value of the $\log$ output ratio. The forecast values of the unemployment gap for 1980-84, given the actual values of the output ratio, allow us to calculate the implied natural rate of unemployment as the actual value of the unemployment rate minus the forecast unemployment gap.

\begin{tabular}{llll}
\hline & Actual $U$ & $\begin{array}{l}\text { Forecast } \\
U \text { gap }\end{array}$ & $\begin{array}{l}\text { Implied } \\
\text { Natural rate }\end{array}$ \\
\hline 1979 & 5.0 & 0.0 & 5.0 \\
1980 & 5.3 & 0.4 & 4.9 \\
1981 & 7.0 & 1.4 & 5.6 \\
1982 & 8.3 & 2.4 & 5.9 \\
1983 & 9.3 & 3.1 & 6.2 \\
1984 & 9.9 & 3.5 & 6.4 \\
\hline
\end{tabular}

\footnotetext{
${ }^{12}$ In the sub-sectors the results are also mixed. In the manufacturing sector, which has previously been the primary focus of proponents of the hysteresis hypothesis, the use of the alternative $Q_{t}-Q_{t}^{H}$ concept of the output ratio unambiguously worsens the fit of the wage
} 
The natural rate of unemployment series implied by our log output ratio thus does not remain fixed at the 1979 level, but rather rises from 5.0 percent in 1979 to 6.4 percent in 1984. Nevertheless, based on the Okun's law relationship of unemplogment and output gaps in Europe prior to 1980, the 1984 output gap of -8.5 percent implies an unemployment gap of 3.5 percent. Further, the estimated 1984 natural rate of unemployment for Europe, 6.4 percent, is roughly the same as the 6.0 percent rate for the U.S. estimated in Gordon (1985).

\section{Conclusion}

The primary theme of the paper is that the previous literature has greatly exaggerated the contrast between the cyclical behavior of labor productivity, wage rates, and price deflators in the U.S. and Europe. Most important, the evidence that the U.S. exhibits more nominal rigidity than Europe is confined to manufacturing. In the aggregate economy and in non-manufacturing the coefficients on the output ratio in the wage equations for the U.S. and Europe are roughly similar. The same similarity arises in the reduced-form inflation equations for the U.S. and Europe. In Japan the familiar result of greater nominal flexibility appears only in the aggregate reduced-form price equation, but not for the two sub-sectors or for the wage equations. Calculated output sacrifice ratios confirm the conclusion that nominal wage rigidity in the U.S. is greater than in Japan, but no greater than in Europe, at least for the aggregate economy. Thus these results undermine the case frequently made against demand expansion in Europe on the ground that a uniquely vertical European aggregate supply curve would cause such an expansion to cause only extra inflation with no bonus of extra output. The sacrifice ratio calculation indicates that substantial extra output would be generated by a nominal demand expansion, albeit with an acceleration of inflation (just as would occur in the U.S. with a similar demand expansion).

The behavior of real wages also receives a new interpretation in this paper. Perhaps most important, the symmetric treatment of the self-employed, with both their income and their labor hours included in measures of labor compensation, labor's share, and the 'wage gap' index, completely eliminates the secular uptrend in the wage gap indexes for Japan and Europe that have been so evident in previous research. Further, the frequent claim that real wages are more rigid in Europe than in the U.S. now requires reinterpretation. In 1984 the European wage gap was lower than the U.S. wage gap in

equation (standard error of estimate rises from 1.82 to 2.28 ) and of the reduced-form price equation (standard error rises from 1.46 to 1.94). In the non-manufacturing sector, however, the hysteresis concept $Q_{t}-Q_{t}^{\mathrm{H}}$ reduces the standard errors from 1.50 to 1.36 and 1.31 to 1.10 , respectively. 
manufacturing (but higher in non-manufacturing), creating problems for classical interpretations of unemployment in Europe where most of the observed decline in employment has occurred in manufacturing. If anything, real wages in Europe and Japan were too flexible rather than too rigid, in the sense that much of the increase in the wage gap indexes in Europe during 1968-70 and in Japan during 1973-74 can be interpreted as autonomous wage push. The component of the higher wage gap that can be attributed to the failure of real wages to adjust to the post-1972 productivity growth slowdown is relatively small.

Finally, the paper contains new results on productivity behavior that are of independent interest, outside of the context of the controversy over real and/or nominal rigidity. The paper confirms the real-wage elasticity of labor input emphasized in several recent papers, but shows that the response of labor input and labor productivity to changes in the real wage is roughly similar in the three countries, rather than being especially high in Europe. The results have the interesting implication that a substantial component of the slowdown in productivity growth, especially after 1972 in U.S. nonmanufacturing and after 1979 in Japan and Europe, can be attributed to a shift from excessive to moderate real wage growth. Finally, the paper finds no evidence to support those who have claimed that productivity exhibits a countercyclical response in Europe in contrast to a procyclical response in the U.S. There is a slight procyclical response of productivity to changes in the output ratio that is almost identical in the U.S. and Europe, in contrast to a more marked procyclical response in Japan.

\section{Data appendix}

\section{A.1. Data for the aggregate economy}

This listing refers to the methods used to compile data for all fourteen countries, which are the United States, Japan, Canada, Austria, Belgium, Denmark, France, West Germany, Italy, Netherlands, Norway, Sweden, Switzerland, and the United Kingdom, except where mentioned otherwise.

\section{Real output $(Q)$}

Real gross domestic product from OECD Statistics Paris: 1985 (PC data diskette, 1985).

Nominal output $(Y)$

Nominal gross domestic output from OECD Statistics Paris: 1985.

Compensation of employees

Total compensation of employees from OECD Statistics Paris: 1985. 
Operating surplus

From OECD Statistics Paris: 1985.

Indirect taxes

From OECD Statistics Paris: 1985.

Import price deflator

The import price deflator is from the International Financial Statistics, series 75 , various issues.

Unemployment rate

Standardized unemployment rate, from the OECD Economic Outlook, table R12. See notes to table 1.

Hours worked

Aggregate hours worked per employee per year, from John P. Martin, at the OECD, covering the period through 1982 or 1983 , depending on the country. Updated to 1984 using the Yearbook of Labour Statistics, 1985 published by the ILO, using the growth rate of weekly hours worked, except for Canada, Germany, Netherlands, and Norway, where it was not needed. No change was assumed for Italy. Since no data were available for Austria, Switzerland and Denmark, the hours for Germany were used for Austria and Switzerland, and hours for Norway were used for Denmark.

Employment

Total employment, taken from Labour Force Statistics, 1963-83 (OECD). Updated to 1984 using for most countries from Quarterly Labour Force Statistics, No. 41985 (OECD) country pages, except for Denmark and Netherlands, for which we used the Yearbook of Labour Statistics, 1985 (ILO), and Belgium, which was guessed to have $1 \%$ growth from the $O E C D$ Economic Outlook description in December 1984.

Entrepreneurial income

Taken from the National Accounts, Vol. II (OECD), various issues, from the old table 6 , line 4.1 , through 1981 , and from the new table 8 , line 5 , after 1981 .

Employment tax

Employment tax rate paid by firms, from Andrew Newell, Centre for Labour Economics, Working Paper 781, series T1.

Income tax

Average rate of income tax paid, from Andrew Newell, Centre for Labour Economics, Working Paper 781, series T2. 


\section{Natural real GDP}

Geometric interpolation between the benchmark years 1960,1972, and 1979, with post-1979 using the same growth rate as for 1972-79. For Japan we used the benchmark years 1960, 1972, 1979, and 1984. For the U.S., Canada and France, where output was at or near a cyclical trough in 1960 , we used the years 1964,1972 , and 1979, with the growth rate for 1964-72 used to extrapolate natural real GNP backwards from 1964 to 1960 .

\section{A.2. The manufacturing sector}

All data were taken from an IMF unpublished quarterly data printout. Sources and methods are given in the appendix of Artus (1984).

Real output

Real domestic manufacturing output.

Wages

Hourly compensation in manufacturing.

Total hours

Total hours in manufacturing.

Employment

Total number of employees in manufacturing.

Value added deflator

The value added deflator for manufacturing.

\section{A.3. The non-manufacturing sector}

Variables for the non-manufacturing sector were calculated by taking the absolute magnitudes of the series for the aggregate economy and subtracting the corresponding absolute figure for the manufacturing sector. Since the manufacturing series were all in index form, the real magnitudes for manufacturing had to be determined from various sources for a particular base year (1972 was used throughout except where specified):

\section{Manufacturing output in current dollars}

Manufacturing output as a percentage of GDP was taken from Historical Statistics 1960-83 (OECD), p. 59, table 5.3. Since this number was not available for Switzerland, the manufacturing output ratio was taken to be equal to the proportion of civilian employment involved in manufacturing, from the same source, p. 37 , table 2.11 . 
Manufacturing employment

Total civilian manufacturing employment was taken from Labour Force Statistics, 1963-83 (OECD) in the country tables for Breakdown by Activities. The series for France, Italy and the Netherlands were obtained from the Yearbook of Labor Statistics, 1980 (ILO) in the series Employment in Manufacturing.

Total manufacturing hours

This was calculated by taking hours per employee per year for the aggregate sector in 1972, and then modifying it to obtain manufacturing hours per employee per year by multiplying it by the ratio of manufacturing hours per week divided by non-agricultural hours per week for 1970, obtained from the Compendium of Social Statistics: 1977 (United Nations). This was then multiplied by 1972 manufacturing employment (determined above) to obtain total hours for manufacturing in 1972. This number is then multiplied by the index series of total manufacturing hours to obtain a series for nominal manufacturing manhours. Subtracting this series from absolute aggregate hours yields absolute nonmanufacturing hours.

\section{Manufacturing compensation}

To determine the absolute level of total compensation for the manufacturing sector for Belgium, Canada, Denmark, France, Germany, Japan, the United Kingdom, and the United States, the labor share of value added in manufacturing was obtained from Bruno and Sachs (1985, p. 162). For Austria, Italy, the Netherlands, Norway, Sweden, and Switzerland the labor share of value added in the aggregate economy was used as a proxy.

\section{References}

Artus, Jacques A., 1984, The disequilibrium real wage hypothesis: An empirical evaluation, IMF Staff Papers 31, no. 2, June, 249-302.

Bean, C.R., P.R.G. Layard and S.J. Nickell, 1985, The rise in unemployment: A multi-country study, Working paper no. 795, Nov. (Centre for Labour Economics, London School of Economics, London).

Blanchard, Olivier J., 1986, Empirical structural evidence on wages, prices, and employment in the U.S., Working paper, May (MIT, Cambridge, MA).

Blanchard, Olivier J. and Lawrence H. Summers, 1986, Hysteresis and the European unemployment problem, NBER working paper no. 1950, June.

Branson, William H. and Julio Rotemberg, 1980, International adjustment with wage rigidity, European Economic Review 13, May, 309-332.

Bruno, Michael and Sachs, Jeffrey, 1981, Supply versus demand approaches to the problem of stagflation, in: H. Giersch, ed., Macroeconomic policies for growth and stability (Institut fur Weltwirtschaft, Universität Kiel).

Bruno, Michael and Sachs Jeffrey, 1985, The economics of worldwide stagflation (Harvard University Press, Cambridge, MA).

Gordon, Robert J., 1977a, World inflation and monetary accommodation in eight countries, Brookings Papers on Economic Activity 8, no. 2, 409-468. 
Gordon, Robert J., 1977b, Interrelations between domestic and international theories of inflation, in: R. Aliber, ed., The political economy of monetary reform (Macmillan, London) 126-154.

Gordon, Robert J., 1982, Why U.S. wage and employment behavior differs from that in Britain and Japan, Economic Journal 92, March, 13-44.

Gordon, Robert J., 1983, A century of evidence on wage and price stickiness in the United States, United Kingdom, and Japan, in: J. Tobin, ed., Macroeconomics, prices, and quantitities (Brookings Institution, Washingt on, DC) 85-121.

Gordon, Robert J., 1984, Unemployment and potential output in the 1980s, Brookings Papers on Economic Activity 15, no. 2, 537-564.

Gordon, Robert J., 1985, Understanding inflation in the 1980s, Brookings Papers on Economic Activity 16, no. 1, 263-299.

Grubb, David, 1986, Topics in the OECD Phillips curve, Economic Journal 96, 55-79, March.

Hamada, Koichi and Kurosaka, Yoshio, 1984, The relationship between production and employment in Japan: Okun's law in comparative perspective, European Economic Review 21 , no. $1 / 2,71-94$, June.

Knoester, A. and N. van der Windt, 1985, Real wages and taxation in ten OECD countries, Erasmus University discussion paper 8501/GM, Rotterdam.

Layard, P.R.G. and S.J. Nickell, 1984, Unemployment and real wages in Europe, Japan, and the U.S., Centre for Labour Economics, London School of Economics, London, Paper no. 677, October.

Newell, A. and J.S.V. Symons, 1985, Wages and employment in the OECD countries, University College, London, Department of Political Economy, Discussion paper 85-24, Sept.

Nordhaus, William, 1972, The world wide wage explosion, Brookings Papers on Economic Activity 3, no. 2, 431-464.

Perry, George L., 1975, Determinants of wage inflation around the world, Brookings Papers on Economic Activity 6, no. 2, 403-435.

Sachs, Jeffrey, 1979, Wages, profits, and macroeconomic adjustment: A comparative study, Brookings Papers on Economic Activity 10, no. 2, 269-319.

Sachs, Jeffrey, 1983, Real wages and unemployment in the OECD countries, Brookings Papers on Economic Activity 14, no. 1, 255-289.

Sachs, Jeffrey, 1986, High unemployment in Europe: Diagnosis and policy implications, NBER working paper no. 1830 , Feb.

Sachs, Jeffrey and Charles Wyplosz, 1986, The economic consequences of President Mitterand, Economic Policy 1, 261-306, April.

Tullio, Giuseppe, 1987, Long-run implications of the increase in taxation and public debt for employment and economic growth in Europe, European Economic Review, this issue.

\section{COMMENTS}

\section{'Productivity, Wages, and Prices Inside and Outside Manufacturing in the U.S., Japan, and Europe' by Robert J. Gordon}

\section{William H. BRANSON}

This paper marks (by the 1987 publication date) seventeen years of Robert Gordon's research on wage and price equations. In 1970, he published an important paper on the acceleration of inflation in the U.S. The wage equation (2) there had essentially the same form as equation (19) in this paper, and the price equation (1) of 1970 looks much like equation (20) here. 
One principal difference is the addition of terms representing prices of traded goods and estimation across countries, representing Gordon's recognition of the importance of international effects and the value of comparative results. A second principal difference is the increase in the coefficient of expected inflation in the wage equation from around 0.5 in 1970 (p. 17) to around unity here in table 5 . This represents the verticalization of the long-run 'Phillips curve since 1970. So in this paper and Gordon (1970) we have a comparison that shows the evolution of our views of wage and price equations since the beginning of the inflation cycle in the late $1960 \mathrm{~s}$.

In my discussion of the paper I will begin with a few points on the theoretical model of wage and price formation, and then discuss the transition from theory to estimating equations. A brief discussion of econometric results will come next. I will conclude with a few general points that return to the theme of wage rigidity.

At the outset, I should remind readers that Gordon does an important aggregation before moving to estimation. Using GNP weights, he creates a 'Europe' aggregate to compare to the U.S. and Japan. This gives us a view of wage and price behavior in Europe on average, not necessarily in Europe in common. If behavior in Europe is diverse, then the European average tells us little about any particular European country. The average is descriptive if the European economies' wage and price behavior has much in common. So the value of the 'European' results here depends on the degree of dispersion vs. similarity of European wage and price behavior.

The theoretical model begins with labor demand, eq. (3), which includes a productivity term, and labor supply, eq. (4), which includes a wage 'aspiration' term. Eq. (5) is an expression for excess demand, and eq. (6) gives its rate of change, which depends on the rate of growth of wages, etc. The twist that Gordon puts into the theory is to derive a Phillips curve by hypothesizing that the nominal wage moves to eliminate excess demand at a rate proportional to its level. This is stated in eq. (7). Since the growth rate of excess demand $x_{t}$ in (6) depends on wage growth, the hypothesis implies that wage growth depends on the level of excess demand $\left(\log X_{t}\right)$. This gives the Phillips curve expressions in eqs. (8) and (11).

As in the 1970 model, the specification here implies that an increase in productivity growth $\theta$ will increase the level of excess demand in the labor market that is consistent with steady deflation. From eq. (14), with $p=p^{\mathrm{e}}$ and $v$ constant, we get $\mathrm{d} X / \mathrm{d} \theta=b / g>0$. This is reflected in Gordon's eq. (18) for the 'shock' natural rate concept. It seems to me an open question whether we believe that a change in the growth rate of productivity should influence the natural rate of unemployment.

Turning to the transition from theory to estimating equations, it is constructive to compare directly eqs. (13) and (20) for $p_{t}$. This comparison shows that the coefficient of $\left(p^{\mathrm{F}}-p\right)$ in eq. (20) is an estimate of $(1-h)$ in 
(13). And the sum of coefficients on $\hat{Q}$ in (20) is the estimate of the coefficient of $m\left(v_{t}\right)$ in (13).

The estimates of eq. (20) are shown in table 6. The coefficients of $\left(p^{\mathrm{F}}-p\right)$ in (20) say that the effect of import prices on the value-added deflator is virtually zero. This can make sense in economies where imports are both final goods and intermediate imports such as oil. An increase in world prices of traded goods, represented by import prices, would raise both competitive output prices and imported input prices. The direct effect on the value-added deflator is not clear.

More surprising are the coefficients of the output ratio in table 6. As Gordon notes, seven of nine coefficients are negative, indicating a fall in the mark-up as demand rises. But the explanation of this result in the paper is not satisfactory. Consider an economy with two sectors, producing traded and non-traded goods, respectively. These would roughly correspond to manufacturing and non-manufacturing in Gordon's sectorization. Suppose the nominal wage rate follows an average of the prices of the two sectors, with perhaps CPI weights. Then an increase in demand, raising the output ratio, should raise the price of non-traded goods. The price of traded goods remains fixed by the world market. Wages rise by an intermediate value. So in this open-economy model the non-traded good price would be highly procyclical, as opposed to Gordon's story. I take the table 6 results as rejecting the mark-up model.

An intriguing aspect of the estimates in tables 2, 5, 6, and 7 is the frequency with which the estimated coefficient for the aggregate economy is outside the range provided by the coefficients for the two sectors in the equations for Japan. For example, in table 7, the aggregate output ratio coefficient is $\mathbf{0 . 4 5}$, while those for manufacturing and non-manufacturing are 0.07 and 0.22 respectively. One suspects that Ms. Compaq or Mr. Rats may have slipped up here.

Finally, a natural comparison to make is between the reduced form estimates in table 7 and the structural equations of tables 5 and 6 . The estimates of coefficients in the latter two tables should combine to give something close to table 7. I did these calculations for the coefficient of the output ratio in the price equation, and found a surprising consistency. The structural and reduced-form estimates fit together very nicely.

On the question of relative wage stickiness, Gordon shows in table 5 that pronounced stickiness of the nominal wage is confined to the U.S. manufacturing sector. This is consistent with my understanding of previous results. Unions and nominal multi-year contracts are more prevalent in U.S. manufacturing than in any other country sectors considered here. In this sense, Gordon's results confirm earlier studies on nominal wage stickness.

On the other hand, I see no test here of real wage rigidity. We have no clear regression that shows the speed of adjustment of real wages to the 
output gap. In fact, flexible nominal wages in non-U.S. manufacturing could be consistent with sticky real wages. Gordon discusses real wage rigidity and classical unemployment in the context of his analysis of movements in labor shares, shown in fig. 2. The most striking result there is the rising share of labor in Japan since 1962. This could be a normal result of development; the labor share is typically lower in a developing country than in the OECD. I would not be surprised if the rising Japanese labor share in the two decades since 1962 simply follows from capital deepening and industrial development. In any event, the labor share is an endogenous variable. As Gordon suggests in his discussion of eq. (24), the effect of an exogenous push in wages on the labor share is ambiguous. So I find movements of the latter unconvincing as evidence for or against real wage rigidity. The issue remains an open one for Europe.

One final question came to my mind as I read the paper. Where are the effects of the big movement in the real exchange rate of the dollar against the EMS and the yen after 1980 on output and employment in manufacturing in this paper? The 1971-84 increase in the trend in Japanese manufacturing output in table 4 may reflect the real depreciation of the yen. I see no effect in the U.S. or Europe equations. For the U.S., Branson and Love (1986) estimate an elasticity of around $-\mathbf{0 . 2}$ for the effect of real dollar appreciation on manufacturing employment. I have seen no estimates for Europe. The point here is that the swing in real exchange rates must have altered the relationship between manufacturing output and wage and price inflation in ways that do not come through in the small $\left(p^{\mathbf{F}}-p\right)$ coefficients in tables 5-7. Robert Gordon has advanced our understanding of wage and price behavior in the OECD in this paper, but he has left a few puzzles yet to be solved.

\section{References}

Branson, W.H. and J.P. Love, 1986, Dollar appreciation and manufacturing employment and output, National Bureau and Economic Research working paper no. 1972, July.

Gordon, R.J., 1970, The recent acceleration of inflation and its lessons for the future, Brookings Papers on Economic Activity 1, 8-41.

\section{COMMENTS}

'Productivity, Wages, and Prices Inside and Outside of Manufacturing in the U.S., Japan, and Europe' by Robert J. Gordon

Heinz KÖNIG

Since the early 70s Robert J. Gordon promotes in a series of studies his ideas about the role of wages and prices for unemployment. The present paper 
picks up the theoretical framework developed in Gordon (1985), the novelty being (a) the distinction between manufacturing and non-manufacturing sectors, (b) a correction of labor's income share by adding the income of selfemployed to labor income, and (c) a comparison of the role of productivity growth, nominal wage rigidity, the real wage gap and hysteresis effects for the three economic areas. Before turning to some critical comments let me stress that $I$, in principle, sympathize with Gordon's findings that 'the case for an excessive wage rate as the crux of the European unemployment has been carried too far'. However, a candidate for the explanation of the low responsiveness of employment to real wage rate reduction seems less the average wage rate but, as has been shown elsewhere for Germany [Franz and König (1986)], changes in the wage structure exhibiting a relative gain of less-qualified labor during the past two decades. Labor Office statistics reveal that particularly these groups share most of the burden of unemployment.

In the following I will focus on three aspects: (i) some ingredients of the theoretical model, (ii) some problems related to data construction and econometric methodology, and (iii) some 'minor' issues concerning aggregation across countries with differences in labor market legislation, participation rates, wage indexation, regulation, and institutional set-up.

(i) As usual in macroeconomics the model posits homogenous labor. Noneconomists may argue that, in fact, heterogeneous labor would be more appropriate for the explanation of the unemployment problem. But, as a macroeconomist, I dismiss this argument. However, one may ask whether the neoclassical framework as used in this paper is adequate for both the manufacturing and non-manufacturing sectors. Since Ehrenberg's work (1971) we have learned that especially in manufacturing deviations of demand from its long-term trend are smoothed by variations in utilization rates of labor, i.e., by overtime or short-time work. In 1983, overtime work ranged from roughly 5 percent in both France and Germany to 8.9 and 10.4 percent of normal working hours in the U.S. and Japan, respectively. May be that differences in the renumeration of overtime work explain the "expected result that there is little cyclical responsiveness of wage rates in U.S. manufacturing, but the unexpected result that there is also less cyclical responsiveness in Japanese manufacturing than in Europe'. In any case it would be preferable to model working hours and persons employed as separate inputs. Recent studies show that nonlinear cost constraints due to overtime or short-time work may have serious implications with respect to the reactions of effective working hours and employment caused by wage rate and/or demand variations. Second, already R. Hall (1985) has questioned the hypothesis of mark-up pricing in particular with respect to international markets. For the non-manufacturing sector in Europe, at least, there exist additional doubts. Agricultural prices are fixed by the EC, prices 
for transportation, electricity, public services are more or less regulated according to rules whatsoever. Naturally, there are important differences between countries in the cyclical response of prices to labor productivity, as has been shown by de Ménil and Westphal (1985).

(ii) As far as the econometrics are concerned one is somewhat troubled by simultaneity biases and autocorrelations of residuals indicating misspecification. Simultaneity not only causes a bias in the direct coefficient but also a bias in the constant term which - in the context of the productivity equation - with regard to the wage coefficient determines the productivity trend variable. Much more important, however, than econometric refinements are the problems related to the correction of labor income's share. As Gordon shows adding the compensation of household entreprenerial income to the compensation of employees has the effect that the secular increase in labor's share in Europe and Japan dissappears almost entirely. The question arises if this is a correct approach. Calculations for Germany, for instance, based upon the assumption that wage income of self-employed corresponds to wage income of identical (or similar) occupational groups of employed persons indicate still an increase of labor's share in the past decades. Finally, I still have some trouble to deduce reduced form coefficients by substituting wage equations estimates into the price equations. Quite substantial differences emerge which may be due to the strategy to save on degrees of freedom but which may be also a result of misspecification.

(iii) Although I have been instructed by a well-known participant of the seminar that poodles look like poodles and that only they themselves know the differences, I still think that some thought on aggregation across countries might be useful with respect to the interpretation of the results. It is ample to state that European countries despite of the EC differ in many ways: 'Ordnungspolitik', labor legislation, institutional framework, policy goals and performance, demographic developments, participation rates and so on. Labor unions play different roles and wage bargaining may be firm and occuaption specific in one country but covering industrial sectors and regional areas in another. Differences in the sectoral composition - shares of agriculture, public services - are evident. Aggregation, therefore, may wipe out important differences in the structure, and hence, in reactions of economic agents. Poodles may look like poodles but behave quite different.

Nevertheless, in spite of this criticism expected from a discussant, I am convinced that Gordon's results with respect to the European wage gap in manufacturing and non-manufacturing offer not only new insights but also a puzzle to those who still believe that real wages are solely responsible for unemployment. 


\section{References}

De Ménil, G. and U. Westphal, 1985, Stabilization policy in France and the Federal Republic of Germany (North-Holland, Amsterdam).

Ehren berg, R.G., 1971, Fringe benefits and overtime behavior (Lexington).

Franz, W. and H. König, 1986, The nature and causes of unemployment in the Federal Republic of Germany since the 1970s: An empirical investigation, Economica 53, Suppl., 219-244.

Gordon, R.J., 1985, Understanding inflation in the 1980s, Brookings Papers on Economic Activity 16, 263-299.

Hall, R.E., 1985, Comment, Brookings Papers on Economic Activity 16, $300 \mathrm{ff}$. 